NBER WORKING PAPER SERIES

\title{
TARIFF PASSTHROUGH AT THE BORDER AND AT THE STORE: EVIDENCE FROM US TRADE POLICY
}

\author{
Alberto Cavallo \\ Gita Gopinath \\ Brent Neiman \\ Jenny Tang \\ Working Paper 26396 \\ http://www.nber.org/papers/w26396 \\ NATIONAL BUREAU OF ECONOMIC RESEARCH \\ 1050 Massachusetts Avenue \\ Cambridge, MA 02138 \\ October 2019
}

This research was conducted with restricted access to Bureau of Labor Statistics (BLS) data. The views expressed herein are those of the authors and do not necessarily reflect the views of the BLS, the Federal Reserve Bank of Boston, the Federal Reserve System, or those of the IMF, its Executive Board, or Management. We are grateful to Rozi Ulics for her substantial efforts as BLS project coordinator, to Florencia Hnilo, Keith Barnatchez, Menglu Xu, and Augusto Ospital for excellent research assistance, and to Chad Bown and Mitali Das for helpful comments and suggestions. Alberto Cavallo is a shareholder of PriceStats LLC, a private company that provided proprietary data used in this paper without any requirements to review the findings prior to their release. Gopinath acknowledges that this material is based upon work supported by the NSF under Grant Number \#1628874. The views expressed herein are those of the authors and do not necessarily reflect the views of the National Bureau of Economic Research.

NBER working papers are circulated for discussion and comment purposes. They have not been peer-reviewed or been subject to the review by the NBER Board of Directors that accompanies official NBER publications.

(C) 2019 by Alberto Cavallo, Gita Gopinath, Brent Neiman, and Jenny Tang. All rights reserved. Short sections of text, not to exceed two paragraphs, may be quoted without explicit permission provided that full credit, including $(\odot)$ notice, is given to the source. 
Tariff Passthrough at the Border and at the Store: Evidence from US Trade Policy

Alberto Cavallo, Gita Gopinath, Brent Neiman, and Jenny Tang

NBER Working Paper No. 26396

October 2019

JEL No. F01,F13,F14,F4

\begin{abstract}
$\underline{\text { ABSTRACT }}$
We use micro data collected at the border and at retailers to characterize the effects of recent changes in US trade policy -- particularly the tariffs placed on imports from China -- on importers, consumers, and exporters. We start by documenting that the tariffs were almost fully passed through to total prices paid by importers, suggesting that incidence has fallen largely on the United States. Since we estimate the response of prices to exchange rates to be far more muted, the recent depreciation of China's renminbi is unlikely to alter this conclusion. Next, using product-level data from several large retailers, we demonstrate that the tariffs' impact on retail prices is more mixed. Some affected product categories have seen sharp price increases, but the difference between affected and unaffected products is generally quite modest, suggesting that retail margins have fallen. These retailers' imports increased after the initial announcement of possible tariffs, but before their full implementation, so the intermediate passthrough of tariffs to their prices may not persist. Finally, in contrast to the case of foreign exporters facing US tariffs, we show that US exporters lowered their prices on goods subjected to foreign retaliatory tariffs compared to exports of non-targeted goods.
\end{abstract}

\author{
Alberto Cavallo \\ Harvard Business School \\ Morgan Hall 287 \\ Soldiers Field \\ Boston, MA 02163 \\ and NBER \\ acavallo@hbs.edu \\ Gita Gopinath \\ Harvard and IMF \\ 700 19th St. NW \\ Washington DC 20431 \\ and NBER (on leave) \\ gopinath@harvard.edu
}

\author{
Brent Neiman \\ University of Chicago \\ Booth School of Business \\ 5807 South Woodlawn Avenue \\ Chicago, IL 60637 \\ and NBER \\ brent.neiman@chicagobooth.edu
}

Jenny Tang

Federal Reserve Bank of Boston

Jenny.Tang@bos.frb.org 


\section{Introduction}

Since 2018, the United States has initiated a large number of significant changes to its trade policies. Most notably, it has imposed import tariffs ranging from 10 to 50 percent on goods including washing machines, solar panels, aluminum, steel, and roughly $\$ 250$ billion of goods from China, and the United States has announced future tariffs affecting nearly $\$ 300$ billion more goods. In response, Canada, China, the European Union (EU), and Mexico have imposed retaliatory tariffs. On a scale not seen since the 1920s, the world's largest economies have passed measures making it far more costly to buy goods from each other. ${ }^{1}$ This paper uses good-level data to assess the impact of these policy changes on US trade prices measured at the border and on US retail prices measured at the store.

We start by studying US import prices using product-level data from the Bureau of Labor Statistics (BLS). The response of import prices to tariffs is of critical interest as this price response contains information on the incidence of trade policy. If the tariff's incidence falls primarily on the exporter, the ex-tariff import price will drop significantly, leaving the importer (who pays the ex-tariff price plus the tariff) largely unaffected. In this case, the importing government's tariff revenues largely come from the foreign exporter's reduced profit margins. Alternatively, if the tariff's incidence falls primarily on the importer, the ex-tariff import price will be relatively stable, raising the total cost the importer must pay (inclusive of tariffs) to buy foreign goods. ${ }^{2}$ Our analyses indicate that the price incidence of US import tariffs falls largely on the United States, consistent with the results obtained using Census unit values in Amiti, Redding, and Weinstein (2019) and Fajgelbaum, Goldberg, Kennedy, and Khandelwal (2019).This result does not, of course, imply that China benefits from the policy. Even if Chinese exporters earned the same price and profit margin per unit exported to the United States, the tariffs would reduce the number of units sold.

We compare import (ex-tariff) price indices constructed for otherwise equivalent goods that are affected and not affected by tariffs and, as of the end of August 2019, find essentially no difference. This is true when comparing price indices for steel products sourced from different

\footnotetext{
${ }^{1}$ See Amiti, Redding, and Weinstein (2019), Bown and Kolb (2019), and Cavallo, Cal, and Laski (2019) for helpful overviews of the policy setting and timelines of the policy changes made.

${ }^{2}$ As discussed in Irwin (2014), despite its theoretical importance for determining who bears the burden of tariffs, few empirical studies evaluate how import prices change with tariffs for large economies such as the United States.
} 
countries, some of which face US import tariffs and others which don't. It is also true when comparing the prices of imports from China that are subject to the tariffs, both when compared to imports of the same types of goods but from non-Chinese suppliers and compared to other types of Chinese goods that aren't subject to tariffs. Using a regression framework, we compare import prices for goods affected and unaffected by the tariffs, controlling for other factors that might influence prices. Controlling only for sectoral inflation rates, these regressions suggest that the typical good imported from China experienced an ex-tariff price decline of 7.6 percent of the tariff rate after one year. This estimate means that a 20 percent tariff, for example, would be associated with a 1.5 percent decline in the ex-tariff price and an 18.5 percent increase in the total price paid by the US importer. When we include additional controls for the exchange rate and foreign producer prices, the estimates become statistically indistinguishable from zero, implying that the ex-tariff price is not economically or statistically impacted by the tariff.

The BLS micro data enable us to study the price dynamics underlying the behavior of these indices. For example, there is no discernible difference in the share of steel imports from countries affected by tariffs experiencing price declines when compared to those steel imports unaffected by the tariffs. The share of goods experiencing ex-tariff price declines in each month remained near the historical average of 5 percent for the affected goods from China, even as the frequency of price declines increased for all other goods to levels closer to 10 percent per month.

Given that these data track the prices of individual goods and are immune to possible changes in the composition of import categories, the BLS micro data are ideal for comparing the passthrough rates of tariffs with those of exchange rate shocks. We estimate that the exchange rate passthrough is 22 percent in the first 12 months that the tariff is in effect, that is a 20 percent dollar depreciation would only raise the dollar price of imports by 4.4 percent, far less than the 18.5 percent discussed above for an equivalent sized tariff. ${ }^{3}$ Our estimated asymmetry in the passthrough rates of exchange rates and tariffs is consistent with the results in Fitzgerald and Haller (2018) and may reflect the role of imported intermediate inputs in production and the perceived difference in the persistence of tariffs versus exchange rate changes. This difference in passthrough rates carries important implications for the consequences of policies such as fiscal

\footnotetext{
${ }^{3}$ The low exchange rate pass-through estimate for the United States is in line with previous estimates such as those in Gopinath, Itskhoki, and Rigobon (2010) and may reflect the high levels of dollar invoicing for US imports, as discussed in Gopoinath, Boz, Casas, Díez, Gourinchas, and Plagborg-Møller (2019).
} 
devaluations and border adjustment taxes, as discussed in Farhi, Gopinath, and Itskhoki (2014) and Barbiero, Farhi, Gopinath, and Itskhoki (2019), and suggests that the depreciation of the Chinese renminbi against the US dollar during the summer of 2019 did little to offset the impact of the tariffs in terms of the prices paid by US importers.

Next, having demonstrated that incidence of the US import tariffs fall largely on the United States, we study the extent to which the price increases faced by importers passed through into higher retail prices or were instead absorbed by lower retailer profit margins. We consider aggregated categories such as washing machines, handbags, tires, refrigerators, and bicycles, and find mixed results, with some sectors exhibiting clear price increases due to the tariffs and others exhibiting stable price dynamics despite the tariffs. It is difficult to study the impact of tariffs using such retail price indices because they are at a level of aggregation that combines meaningful shares of goods that are both affected and not affected by the tariffs. To get around this problem, we collect millions of online prices from two multi-channel retailers - both in the top 10 of US retailers in terms of revenues - where we can identify whether or not individual goods are affected by the import tariffs.

Surprisingly, despite observing a stark increase in the overall cost (inclusive of tariffs) paid by US importers for certain Chinese goods, we detect only a minor increase in the prices set by the two retailers for these goods relative to those unaffected by tariffs. Our estimates suggest that a 20 percent tariff is associated with a 0.9 percent increase in the retail prices of affected household goods (such as dishes, furniture, linens, toaster ovens, towels, and umbrellas) and a 1.4 percent increase in the retail prices of affected electronics products after one year. While these estimated price increases are economically and statistically greater than zero, they are not easily visible in the aggregated retail price indices that we construct to compare affected and unaffected imports. Our results suggest that retailers are absorbing a significant share of the increase in the cost of affected imports by earning lower profit margins on those goods. ${ }^{4}$ This empirical evidence supports the idea that a more complete understanding of the full supply chain, from "at-the-dock" importers through to final retailers, is important to capture the full implications of any trade policy, a point made theoretically in Cole and Eckel (2018).

\footnotetext{
${ }^{4}$ Consider a back-of-the-envelope calculation. Imagine that the total cost of an imported good (inclusive of tariffs) accounts for half of the retailer's marginal cost for that good. Our estimated regression results suggest that a 20 percent tariff would cause the import price to increase by 18.6 percent. If margins remain unchanged, all else equal, the retail price for that good would have to increase by 9.3 percent.
} 
Rather than retailers earning lower profits, another possibility - following the logic and analysis in Flaaen, Hortaçsu, and Tintelnot (2019) and Amiti, Redding, and Weinstein (2019) - is that in response to the tariffs, domestic producers raise their prices to retailers on goods that compete with the imports. Or alternatively, retailers may simply be increasing prices throughout the sectors that are exposed to the import tariffs, thus earning higher margins on those goods not impacted by tariffs. These dynamics would be consistent with our finding that the retail prices of goods affected by import tariffs have evolved similarly to those for goods unaffected by tariffs. These possible responses by US producers and retailers would imply different price behavior for US and non-US retail prices, however, and we do not find strong evidence consistent with this prediction. We compare the pricing behavior of several large retailers that sell in the United States and in Canada, including the two retailers used in our baseline analysis. Despite comparing prices set by the same retailer and focusing on the same goods, we do not find evidence that the tariffs brought about meaningfully higher retail inflation in the United States when compared to Canada.

Does it matter whether the higher import prices result in lower retailer margins or higher consumer prices? Among many other implications, we argue that it implies this first year of data only reveals the short-run impact of the global tariffs. We provide evidence that retailers, when the tariffs were announced, increased their import shipments from China in efforts to greatly expand their inventories and capacity to absorb further tariff hikes. Starting around August 2017, when the US Trade Representative was directed to determine whether to initiate a Section 301 investigation against China, and when then actual investigation was in fact initiated, the two retailers we study expanded their monthly tonnage imported from China by about 40 percent. This tariff "front-running" may have moderated the extent to which retail profit margins have declined in financial reports. Furthermore, when the tariffs were imposed in summer 2018, both retailers again increased their imported tonnage from China, perhaps because the tariff rates at that time were lower than the announced future rates. We speculate that if the tariffs remain in place for much longer, pressure on these retailers will likely rise. ${ }^{5}$ We would expect this to result in some future combination of greater passthrough into consumer prices or a larger reduction in

\footnotetext{
${ }^{5}$ Some pressure may be eased as US importers divert their supply chains away from China. We document that China's share of the tonnage imported by these two retailers dropped from 97 percent prior to the tariffs to 80 percent afterward.
} 
U.S. ex-tariff import prices.

Finally, we turn to BLS export prices, which we use to gauge whether US exporters maintained their prices in the face of retaliatory tariffs impacting their foreign sales. These tariffs were applied by many different governments and vary more than the US import tariffs in terms of their timing, scope, and scale. Simple comparisons of export price indices of affected and unaffected products, however, suggest that affected exporters have dropped their (pre-tariff) prices by about 7 percent in response to retaliatory tariffs that average about 15 percent. We estimate regressions for exports that are equivalent to what we did for imports and find that, controlling for sectoral inflation rates, ex-tariff export prices declined by 48.1 percent of the tariff rate after one year. These aggregate and micro analyses therefore reveal that the recent tariffs applied by foreign governments on US exports have affected total foreign import prices far less than was the case for the recent US tariffs. US tariff passthrough into US import prices was nearly 95 percent after one year, whereas foreign tariff passthrough into foreign import prices was perhaps as low as 50 percent.

Why did US exporters choose to drop their prices so much more in the face of retaliatory tariffs than did Chinese exporters in the face of the US import tariffs? We show that the decline in the relative export price of retaliated-upon products is almost entirely driven by the pricing on US shipments of non-differentiated and agricultural goods to China, rather than on US shipments of differentiated goods and US shipments to countries other than China. A far larger share of the affected goods imported by the United States from China are differentiated goods that may be more difficult to source elsewhere than is the case for the affected goods exported by the United States to China.

\section{Environment}

Before turning to our empirical analysis, we present a simple static framework to motivate our regression specifications. Consider a supply chain with the following sequence. A firm located in country $j$ exports good $i$ at time $t$ to a US importer at a US dollar price $P_{i, j, t}^{\mathcal{I}}$. The importer then pays an ad-valorem tariff $\tau_{i, j, t}$ to the government, resulting in a total import cost of $P_{i, j, t}^{\mathcal{I}}\left(1+\tau_{i, j, t}\right)$. Finally, the importer combines this input with proportional marketing and distribution costs before selling that good to consumers at a retail price $P_{i, j, t}^{\mathcal{R}}$ (also in dollars). 
We assume the foreign exporter manufactures the good using a Cobb-Douglas technology with constant returns to scale that uses some inputs (like labor) whose prices are sticky in the local currency and others (like imported inputs) whose prices are not. We therefore write the exporter's marginal cost, translated to US dollars, as $C_{i, j, t}^{\mathcal{I}}=A_{i, j, t}\left(W_{j, t} S_{j, t}\right)^{\phi}$, where $A_{i, j, t}$ captures the combined effect of the firm's productivity and the cost of inputs with prices sticky in the foreign currency, $W_{j, t}$ represents the price of the sticky local currency input (such as the wage), $S_{j, t}$ is the number of US dollars purchased by each unit of country $j$ 's currency, and $\phi$ is the output elasticity of the exporter's production function with respect to that local currency input.

The exporter's price equals a markup over this marginal cost: $P_{i, j, t}^{\mathcal{I}}=\mu_{i, j, t}^{\mathcal{I}} C_{i, j, t}^{\mathcal{I}}$. The exporter incurs a cost when it changes its price for the good, so will only do so when the resulting increase in operating profits exceeds this cost. When the exporter changes the price, its markup $\mu_{i, j, t}^{\mathcal{I}}$ is assumed to be a function of its market share, which we assume depends on its own price relative to an industry price level $P_{t}^{\mathcal{I}}$, multiplied by the tariff, since import demand for the good depends on its price inclusive of tariffs. We therefore write: $\mu_{i, j, t}^{\mathcal{I}}=\mu^{\mathcal{I}}\left(\left(1+\tau_{i, j, t}\right) P_{i, j, t}^{\mathcal{I}} / P_{t}^{\mathcal{I}} ; \boldsymbol{\theta}^{\mathcal{I}}\right)$, where $\theta^{\mathcal{I}}$ collects parameters governing the shape of import demand and use $\Gamma^{\mathcal{I}} \equiv-\frac{\partial \ln \mu^{\mathcal{I}}(x)}{\partial \ln x}$ to denote the opposite of the elasticity of the markup. ${ }^{6}$ We take logs, differentiate, and substitute these relationship to write:

$$
d \ln \left(P_{i, j, t}^{\mathcal{I}}\right)=\gamma^{\mathcal{I}} d \ln \left(1+\tau_{i, j, t}\right)-\gamma^{\mathcal{I}} d \ln \left(P_{t}^{\mathcal{I}}\right)+\beta^{\mathcal{I}} d \ln \left(W_{j, t}\right)+\beta^{\mathcal{I}} d \ln \left(S_{j, t}\right),
$$

where $\gamma^{\mathcal{I}} \equiv-\frac{\Gamma^{\mathcal{I}}}{1+\Gamma^{\mathcal{I}}}$ is the passthrough of tariffs to the ex-tariff import price and $\beta^{\mathcal{I}} \equiv \frac{\phi}{1+\Gamma^{\mathcal{I}}}$ is the passthrough of local costs and exchange rates to the import price. Since $\gamma^{\mathcal{I}}$ equals tariff passthrough to ex-tariff import prices, $1+\gamma^{\mathcal{I}}$ equals the rate of passthrough from tariffs to total (i.e. inclusive of tariff) import prices.

Equation (1) forms the basis for our empirical strategy. Because some exporters may choose not to change prices, some of our estimates using trade data are conditional on observing a price change. In the extreme case with $\gamma^{\mathcal{I}}=-1$, it would imply that ex-tariff import prices fell proportionately with tariffs and the total price of imports remained constant. This hypothetical would reveal that the passthrough of tariffs to the total import cost was zero (i.e. $1+\gamma^{\mathcal{I}}=0$ ) and that the tariff's cost fell entirely on the exporter. Alternatively, if $\gamma^{\mathcal{I}}$ were estimated to equal 0 ,

\footnotetext{
${ }^{6}$ We assume the exporter is too small to internalize any impact on the final retail price charged by the importer.
} 
it would imply that ex-tariff import prices did not change with the tariffs, but rather, that the tariffs were fully passed through to the total import price (i.e. $1+\gamma^{\mathcal{I}}=1$ ). The importer, in this case, bears much of the tariff's cost. We estimate a closely related specification in our analysis of passthrough to retail prices.

\section{$3 \quad$ US Imports}

We start with our analysis of US import price data collected by the International Pricing Program at the BLS. Prices are collected monthly by survey and are used to construct import price indices. As a result, one strength of working with the BLS data relative to the Census data is the ability to trace the import price of an identical good over time. ${ }^{7}$ Gopinath and Rigobon (2008) provides additional detail on the BLS dataset and its construction.

The data include many observations deemed "unusable" for BLS price indices, generally due to the lack of an actual transaction for a given good in a given month. Our baseline treatment fills forward the most recent usable price in the place of unusable observations. We further weight all analyses using expenditures at the "classification group" level, and begin all our analyses in 2005, the year when these weights become available. We drop all price changes that exceed $2.3 \log$ points in magnitude and focus only on market transactions. ${ }^{8}$ We conduct the analysis only using prices of trades invoiced in US dollars, a group which represents over 94 percent of US trade occurring over our sample, and also exclude petroleum products. We only use data involving partner countries for which we have data on aggregate prices and exchange rates (our data on these macro variables cover 182 countries).

\subsection{US Imports from China}

Import tariffs were enacted on China in three waves during 2018. First, in July, the United States imposed a 25 percent ad-valorem tariff on roughly $\$ 34$ billion of imports. Second, in August, the 25 percent tariff was extended to cover another $\$ 16$ billion in shipments. Third, in September, a 10 percent tariff was applied to roughly $\$ 200$ billion in goods. In May of 2019, the tariff on that

\footnotetext{
${ }^{7}$ Some weaknesses of the BLS data are that these prices are sampled and purchase quantities are not available at the product level.

${ }^{8}$ More than one-third of the BLS import prices are non-market transactions such as intrafirm trade or shipments among related parties. Neiman (2010) studies the differences in these market and related party prices.
} 
third wave of goods was increased from 10 to 25 percent. ${ }^{9}$ Since goods in the BLS data can be concorded with harmonized system (HS) codes and we know the provenance of each shipment, we can easily associate each good with the tariff rate that applies to it in each month.

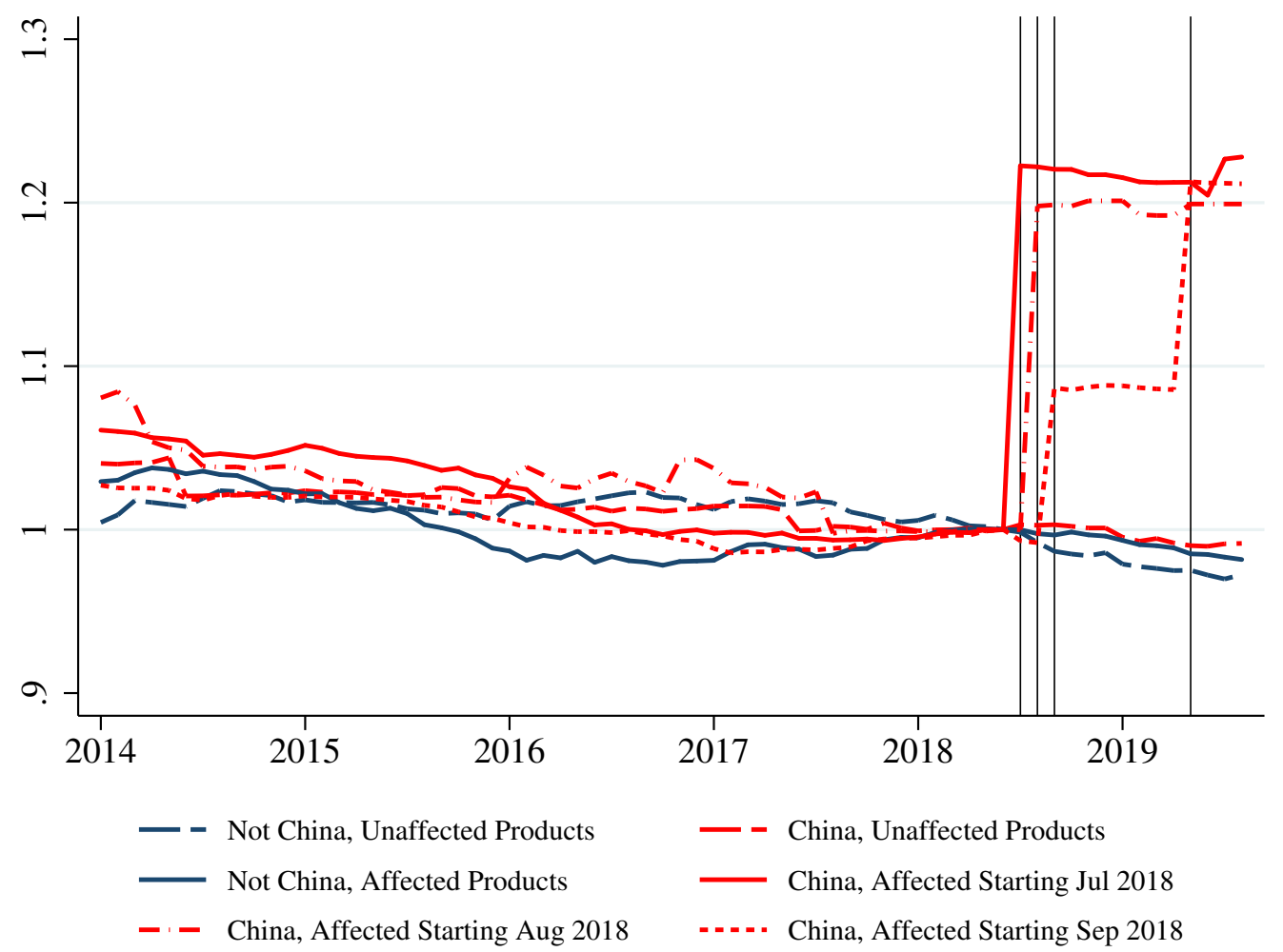

Figure 1: Import Price Indices, by China Tariff Wave

Figure 1 plots log price indices - inclusive of tariffs - constructed for six mutually exclusive and collectively exhaustive groups of US imports. The first two groups include the set of products that are unaffected by the 2018-2019 tariff policy changes, divided into those exported by China and those exported by other countries. The third group includes products with HS codes that are affected, but which do not face the tariffs because they are not imported from China. ${ }^{10}$ The fourth, fifth, and sixth groups, then, capture imports from China that are affected by the three waves of tariff changes. ${ }^{11}$ The price indices are normalized to 1 in June 2018, the last month

\footnotetext{
${ }^{9}$ Additional tariffs have been announced that will apply to nearly all of the currently unaffected imports from China. These tariffs were not in place during the period covered by our data.

${ }^{10}$ Throughout the paper, we match goods to their 6-digit HS codes and assume that the associated tariff is the highest value among the corresponding 8-digit HS codes, which is the level at which the tariff code is written. Though imperfect, this assumption holds exactly for over 95 percent of the 6-digit codes.

${ }^{11}$ Here, and in the rest of our analyses of the tariff on Chinese imports, we exclude a small number of goods that are impacted both by a China tariff and another product-based tariff (such as steel and aluminum products, lumber, washing machines, and solar panels). We additionally exclude data on imports from India because in June 2019 the
} 
prior to the imposition of US tariffs on China. The plots include three vertical lines in 2018 corresponding to the three waves of tariffs starting that summer. We plot a fourth vertical line in May 2019, when the tariffs on the third wave of goods increased from 10 to 25 percent.

All six categories exhibit very similar and mildly deflationary trends for the four years prior to the tariffs. Affected products imported from countries other than China had the least deflation, with prices dropping by an annual average rate only slightly above 0 percent over the period. Other goods experienced annual deflation averaging closer to 1.0 or 1.5 percent over the same period. The products never targeted by tariffs, either because they are not among the affected good types or are among the affected good types but imported from countries other than China, continue these trends through 2018 and into early 2019. By contrast, each affected good category from China saw an immediate jump in its price, inclusive of tariffs, during the month that the policy was implemented. The scale of the jumps are only slightly below the scale of the tariff rates, consistent with the fact that the ex-tariff prices did not exhibit meaningful breaks from their trends.

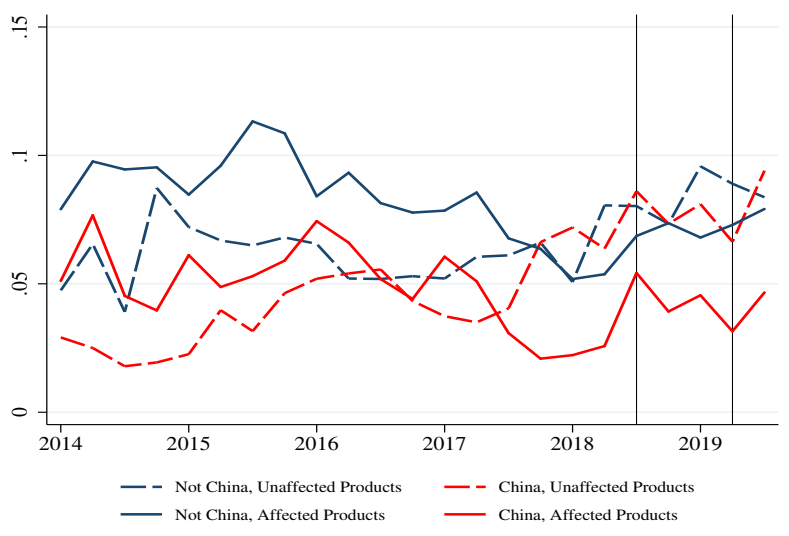

(a) Price Decreases

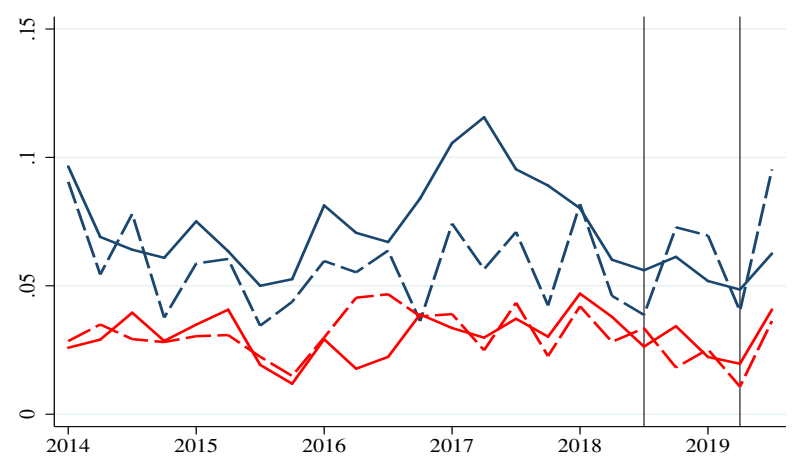

- - Not China, Unaffected Products $\quad$ - China, Unaffected Products

(b) Price Increases

Figure 2: Frequency of Monthly Price Changes (Quarterly Averages)

The price indices in Figure 1 reflect the frequency of import price changes as well as the size of any non-zero price changes. Since the BLS data are at the level of individual goods, we can observe if the stability of ex-tariff prices reflects "wait and see" behavior or any other important changes in the patterns of price stickiness. Figure 2(a) plots the share of prices each United States ended India's developing country exemption, which had given it access to US most favored nation tariff rates. 
month which decrease, averaged across the three months in each quarter to smooth the otherwise volatile series. It does this separately for four categories of goods: those of the type unaffected by the tariffs and imported from countries other than China, those unaffected even though they are imported from China, those affected but imported from outside of China, and those affected and imported from China, where only this latter group includes goods where the importer must actually pay a tariff. There are no obvious differences across the four groups and, if anything, the prices of products in that last set of goods appear to be the most stable. Figure 2(b) plots the equivalent statistics for price increases and, again, finds little evidence of important changes in pricing behavior brought about by the tariffs.

Above, we established that ex-tariff price indices do not evolve differently for Chinese goods targeted by the tariff policy and that tariffs do not appear to have changed the price stickiness of these goods. We now conclude our analysis of the Chinese import tariffs with regression analyses capable of controlling for multiple factors other than tariffs and the exporter country that might matter for pricing trends. Furthermore, we can use the framework to compare the passthrough to importer prices of the tariffs with an equivalent-sized movement in the exchange rate.

Motivated by Equation (1), we consider two types of regression specifications. The first is run with all monthly observations, including periods in which there is no price change. We estimate:

$$
\begin{aligned}
\Delta \ln \left(P_{i, j, k, t}^{\mathcal{I}}\right) & =\delta_{k}^{\mathcal{I}}+\phi_{\mathrm{CN}}^{\mathcal{I}, \Omega}+\phi_{\mathrm{CN}}^{\mathcal{I},-\Omega}+\sum_{l=0}^{11} \gamma_{\mathrm{CN}, l}^{\mathcal{I}} \Delta \tau_{\mathrm{CN}, k, t-l} \\
& +\sum_{l=0}^{11} \beta_{l}^{\mathcal{I}, S} \Delta \ln \left(S_{j, t-l}\right)+\sum_{l=0}^{11} \beta_{l}^{\mathcal{I}, X} \Delta \ln \left(X_{j, t-l}\right)+\epsilon_{i, j, k, t},
\end{aligned}
$$

where $P_{i, j, k, t}^{\mathcal{I}}$ is the ex-tariff price of item $i$ imported from country $j$ in sector $k$ at month $t$ and where sectors are defined as the BLS's "primary stratum lower", which is a level of disaggregation that lies between the HS4 and HS6 levels. ${ }^{12}$ The fixed effect $\delta_{k}^{\mathcal{I}}$ therefore captures an average sectoral inflation rate. We let $k \in \Omega$ denote those sectors that are affected by the tariff, so the fixed effects $\phi_{\mathrm{CN}}^{\mathcal{I}, \Omega}$ and $\phi_{\mathrm{CN}}^{\mathcal{I},-\Omega}$ allow for a constant deviation from those sectoral inflation rates for affected and unaffected goods imported from China, respectively.

The term $\Delta \tau_{\mathrm{CN}, k, t-l}$ equals the log gross additional tariff rate that is newly applied in a particular month to imports from China in sector $k$ at time $t-l$, and would equal $0.22(\approx$

\footnotetext{
${ }^{12}$ This is the lowest level of aggregation for which the BLS deems indices to be publishable.
} 
$\ln (1.25))$, say, to correspond with the introduction of a 25 percent tariff. The lag structure allows monthly price changes to differentially reflect changes in tariffs that went into effect recently compared with further in the past. To evaluate the cumulative impact of the tariffs one year after they were applied, we report the point estimate and standard error of $\sum_{l=0}^{11} \gamma_{\mathrm{CN}, l}^{\mathcal{I}}$. This gives the estimate of the tariff rate passthrough after the current month plus 11 lags. Finally, $S_{j, t-l}$ is the value of country $j$ 's currency in US dollars at time $t-l$ and $X_{j, t-l}$ is the producer price index in $j$ at $t-l$. The point estimate of $\sum_{l=0}^{11} \beta_{l}^{\mathcal{I}, S}$ therefore constitutes our estimate of exchange rate passthrough (ERPT) after one year (i.e. the current month plus 11 lags).

\begin{tabular}{|c|c|c|c|c|c|}
\hline & & (1) & $(2)$ & (3) & $(4)$ \\
\hline Tariffs 1 yr. & $\left(\sum_{l=0}^{11} \gamma_{\mathrm{CN}, l}^{\mathcal{I}}\right)$ & $\begin{array}{c}-0.079 * * * \\
(0.026)\end{array}$ & $\begin{array}{c}-0.076^{* * *} \\
(0.028)\end{array}$ & & $\begin{array}{l}-0.018 \\
(0.030)\end{array}$ \\
\hline ERPT 1 yr. & $\left(\sum_{l=0}^{11} \beta_{l}^{\mathcal{I}, S}\right)$ & & & $\begin{array}{c}0.219^{* * *} \\
(0.027)\end{array}$ & $\begin{array}{c}0.221^{* * *} \\
(0.027)\end{array}$ \\
\hline PPI PT 1 yr. & $\left(\sum_{l=0}^{11} \beta_{l}^{\mathcal{I}, X}\right)$ & & & $\begin{array}{c}0.019 \\
(0.070)\end{array}$ & $\begin{array}{c}0.012 \\
(0.073)\end{array}$ \\
\hline $\begin{array}{l}\text { China } \\
\text { Affected }\end{array}$ & $\left(\phi_{\mathrm{CN}}^{\mathcal{I}, \Omega}\right)$ & & $\begin{array}{c}0.000 \\
(0.000)\end{array}$ & & $\begin{array}{l}-0.000 \\
(0.000)\end{array}$ \\
\hline $\begin{array}{l}\text { China } \\
\text { Not-Affected }\end{array}$ & $\left(\phi_{\mathrm{CN}}^{\mathcal{I},-\Omega}\right)$ & & $\begin{array}{l}-0.000 \\
(0.001)\end{array}$ & & $\begin{array}{l}-0.001 \\
(0.001)\end{array}$ \\
\hline & $\begin{array}{l}\text { Adj. } R^{2} \\
\text { Obs. } \\
\text { Sector FEs? }\end{array}$ & $\begin{array}{c}0.000 \\
820,318 \\
\text { No }\end{array}$ & $\begin{array}{c}0.003 \\
820,318 \\
\text { Yes }\end{array}$ & $\begin{array}{c}0.004 \\
820,318 \\
\text { Yes }\end{array}$ & $\begin{array}{c}0.004 \\
820,318 \\
\text { Yes }\end{array}$ \\
\hline
\end{tabular}

Notes: Robust standard errors in parentheses. ${ }^{* * *},{ }^{* *}$, and ${ }^{*}$ denote statistical significance at the 1,5 , and 10 percent level.

Table 1: Regression Analysis of Chinese Import Tariffs Using Monthly Data

Table 1 reports the results from estimating Equation (2) using monthly data from January 2005 to August 2019. Column (1) reports the cumulative impact of 12 months of tariffs in a specification that does not condition on any other variables. The estimated coefficient of -0.079 means, for example, that a 10 percent tariff would be associated with a 0.8 percent lower ex-tariff 
price and a 9.2 percent higher overall price faced by the importer. Column (2) adds sectoral fixed effects plus the China-specific fixed effects $\phi$ and the magnitude of this estimate is roughly preserved. Column (3) removes the tariff and China-specific covariates and estimates a relatively standard passthrough regression, showing that when the dollar depreciates by about 10 percent, import prices rise by about 2.19 percent. Finally, in Column (4) we estimate the tariff impact using a specification that also controls for sectoral effects and exchange rates. Our exchange rate passthrough estimate is largely unchanged but the tariff response drops to a value that is statistically indistinguishable from zero.

Next, we consider a second type of regression in which we only include non-zero price changes. In particular, for each price spell of good $i$, we define $t_{1}$ as the first month of the spell and $t_{0}$ as the first month of the previous spell. We then estimate:

$$
\begin{aligned}
\frac{1}{t_{1}-t_{0}} \ln \left(\frac{P_{i, j, k, t_{1}}^{\mathcal{I}}}{P_{i, j, k, t_{0}}^{\mathcal{I}}}\right) & =\delta_{k}^{\mathcal{I}}+\phi_{\mathrm{CN}}^{\mathcal{I}, \Omega}+\phi_{\mathrm{CN}}^{\mathcal{I},-\Omega}+\gamma^{\mathcal{I}} \tau_{\mathrm{CN}, k, t_{1}} \\
& +\beta^{\mathcal{I}, S} \frac{1}{t_{1}-t_{0}} \ln \left(\frac{S_{j, t_{1}}}{S_{j, t_{0}}}\right)+\beta^{\mathcal{I}, X} \frac{1}{t_{1}-t_{0}} \ln \left(\frac{X_{j, t_{1}}}{X_{j, t_{0}}}\right)+\epsilon_{i, j, k, t_{1}, t_{0}},
\end{aligned}
$$

where the term $\left(t_{1}-t_{0}\right)$ serves to scale the changes so all correspond to a monthly frequency. In this specification, $\tau_{\mathrm{CN}, k, t_{1}}$ equals the tariff level for goods from China in sector $k$ at $t_{1}$ and is meant to allow estimates of $\gamma$ to capture differential inflation rates for goods impacted by the tariffs. ${ }^{13}$ Since the changes in the price, exchange rate, and producer price index are all scaled to represent monthly changes, we report the estimate of $\gamma^{\mathcal{I}}$ multiplied by 12 to capture the annualized equivalent of the change in inflation associated with goods affected by the tariffs. Given this, plus the fact that these regressions drop any observations where the left-hand-side equals zero, these estimates would be expected to be larger in magnitude than what was found in Table 1.

Table 2 reports the estimates of Equation (3). The results are qualitatively consistent with those from the monthly specifications shown in Table 1. The import tariffs on Chinese goods are associated with changes in the ex-tariff import price that are economically or statistically insignificant, depending on the specification. By contrast, exchange rate passthrough in these estimates rises to roughly 38 percent.

\footnotetext{
${ }^{13}$ This specification may not be well-suited for thinking about changes where $t_{0}$ is after the tariff was imposed, but our results appear qualitatively robust to dropping such observations.
} 


\begin{tabular}{|c|c|c|c|c|c|}
\hline & & (1) & (2) & (3) & (4) \\
\hline $\begin{array}{l}\text { Tariffs } \\
\text { (Annualized) }\end{array}$ & $12 \times \gamma^{\mathcal{I}}$ & $\begin{array}{l}-0.228 \\
(0.171)\end{array}$ & $\begin{array}{c}-0.109 \\
(0.187)\end{array}$ & & $\begin{array}{c}0.006 \\
(0.188)\end{array}$ \\
\hline ERPT & $\beta^{\mathcal{I}, S}$ & & & $\begin{array}{c}0.382^{* * *} * \\
(0.052)\end{array}$ & $\begin{array}{c}0.381^{* * * *} \\
(0.052)\end{array}$ \\
\hline PPI PT & $\beta_{l}^{\mathcal{I}, X}$ & & & $\begin{array}{c}0.757^{* * * *} \\
(0.110)\end{array}$ & $\begin{array}{c}0.766^{* * *} \\
(0.111)\end{array}$ \\
\hline $\begin{array}{l}\text { China } \\
\text { Affected }\end{array}$ & $\phi_{\mathrm{CN}}^{\mathcal{I}, \Omega}$ & & $\begin{array}{c}0.004^{* * *} \\
(0.002)\end{array}$ & & $\begin{array}{c}0.004^{* * * *} \\
(0.002)\end{array}$ \\
\hline $\begin{array}{l}\text { China } \\
\text { Not-Affected }\end{array}$ & $\phi_{\mathrm{CN}}^{\mathcal{I},-\Omega}$ & & $\begin{array}{l}0.002^{*} \\
(0.001)\end{array}$ & & $\begin{array}{c}0.003^{* *} \\
(0.001)\end{array}$ \\
\hline & $\begin{array}{l}\text { Adj. } R^{2} \\
\text { Obs. } \\
\text { Sector FEs? }\end{array}$ & $\begin{array}{c}0.000 \\
99,406 \\
\text { No }\end{array}$ & $\begin{array}{c}0.006 \\
99,406 \\
\text { Yes }\end{array}$ & $\begin{array}{c}0.017 \\
99,406 \\
\text { Yes }\end{array}$ & $\begin{array}{c}0.018 \\
99,406 \\
\text { Yes }\end{array}$ \\
\hline
\end{tabular}

Notes: Robust standard errors in parentheses. ${ }^{* * *},{ }^{* *}$, and ${ }^{*}$ denote statistical significance at the 1,5 , and 10 percent level.

Table 2: Regression Analysis of Chinese Import Tariffs, Conditional on Price Changes

\subsection{Tariffs on Steel Imports}

Prior to the tariffs placed on Chinese imports in July 2018, the United States placed a 25 percent tariff on steel imports from all countries in March 2018. At the time, exemptions were made for imports from Argentina, Australia, Brazil, Canada, Mexico, the European Union (EU), and South Korea. By June, the exemptions were lifted for Canada, the EU, and Mexico, so June 2018 effectively brought a second wave of steel tariffs. The exemptions for the remaining countries were made permanent. Equivalent to our analysis in Figure 1, therefore, we can compare import price indices - inclusive of tariffs - for steel imports from these three groups of countries.

Figure 3 shows the evolution of steel prices, which had been quite volatile during the preceding four years. The vertical lines indicate the initiation of steel tariffs for two groups of countries in March and June 2018. Steel prices from all three groups tracked each other relatively closely until the steel tariffs were introduced. After that point, prices on imports from all countries rose, but imports from the affected countries (shown in red) jumped to roughly 20 percent above 


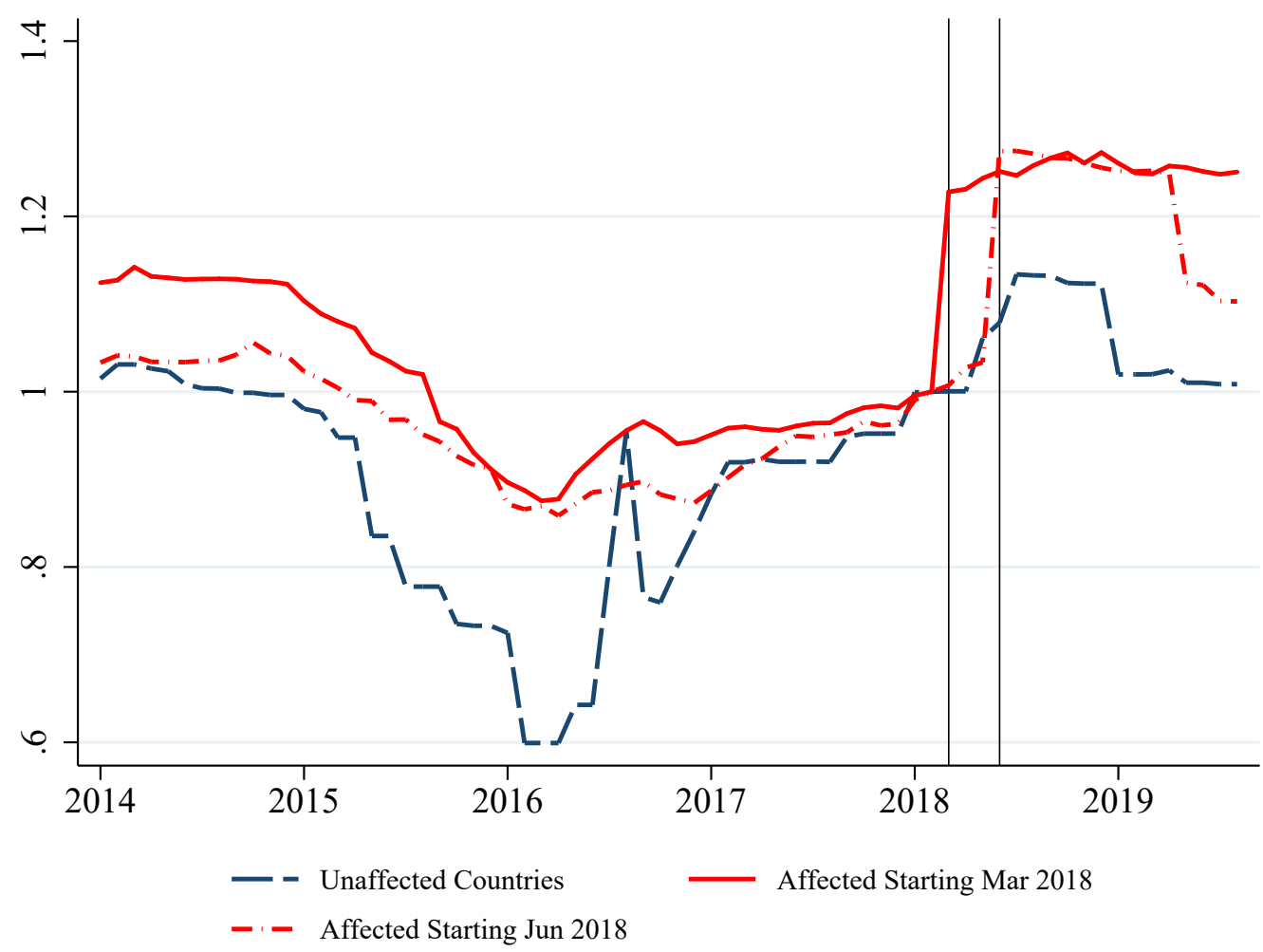

Figure 3: Steel Import Price Indices, by Tariff Wave

those from unaffected countries. ${ }^{14}$

\subsection{Summary of Results on US Import Tariffs}

Whether looking at imports from China or imports of steel products, and whether looking at aggregated price indices or regression estimates that use variation across individual products, our analyses paint a similar picture of the 12-month price response to US import tariffs imposed in 2018 and 2019. Ex-tariff prices do not obviously behave differently for goods affected by trade policy compared to those that were not affected, implying the tariffs exhibited nearly complete passthrough into the total import cost and that the incidence of the tariffs lies largely with the United States.

Using the same data, methods, and time period, we estimate that the passthrough of exchange rate changes into import prices are in the range of 25 to 35 percent after one year, consistent

\footnotetext{
${ }^{14}$ For Figure 3, we allocate products into these three groupings statically, so the red dashed line drops in May 2019 simply because the US steel tariffs were dropped then for imports from Canada and Mexico. Steel imports from the EU, which were also imposed in June of 2018 and are included in that dashed red line, remain affected. Regression analyses suggest similar conclusions but estimates are imprecise given the small number of imported steel products.
} 
with estimates found in a large literature, a rate much lower than the passthrough rate of tariffs into total import prices. This finding suggests being cautious when interpreting results obtained from using standard models in trade and international macroeconomics that assume a symmetric response to these two types of shocks. For example, the implications from these standard models might be more appropriately applied to longer-run outcomes, or they might be amended to allow for more uncertainty or mean-reversion in the shocks, features that might naturally explain our finding. Furthermore, as a practical matter, our result suggests that the recent depreciation of the Chinese renminbi did not offset the impact of the tariffs for US importers.

Having established the behavior of US import prices, we now ask how the tariffs impacted prices further downstream in the US economy, such as by retailers to final consumers. In the next section, we use millions of prices collected online from key US retailers to evaluate the passthrough of tariffs to retail prices.

\section{US Retail Prices}

We start this section with an analysis of the pricing dynamics in categories of goods that are overwhelmingly impacted by the tariffs. For example, we study the retail prices of washing machines and handbags because the United States placed tariffs on all imported washing machines, except those from Canada and a group of developing countries, and affected imports from China account for a very large share of the US handbag market. These analyses do not specifically distinguish between the prices of affected and unaffected goods. To do so, the second part of this section focuses on data from two large retailers where we can assign their goods to HS categories and to countries of origin, allowing us to compare pricing behavior within retailer for goods hit by the tariffs with goods that are exempted. We further compare across countries to see if US retail prices have generally risen relative to those in other countries that did not impose tariffs. Overall, while we find some evidence that the tariffs have passed through into higher retail prices, the effects are clearly more muted than what we demonstrated for total import prices, implying that - at least so far - retailers have absorbed much of the higher costs associated with the tariffs by earning lower margins on their sales.

We conclude this section by presenting some evidence that retailers did some front-running of the tariffs, meaning that they built up inventories before the highest tariffs went into effect, 
and that they started diverting at least some of their orders to non-Chinese suppliers. These margins of adjustment may have enabled retailers to avoid raising consumer prices by more, but may also suggest that the price response to the tariffs, to date, might be an imperfect indicator of what it will be in the future.

\subsection{Data from the Largest US Retailers}

We start our retail-level analyses by studying daily prices for washing machines. Nearly all washing machine imports (other than the few exceptions mentioned above) faced tariffs, regardless of their provenance, with statutory rates ranging from 20 to 50 percent starting in January 2018. This sector has received significant attention from academics, and is the focus of Flaaen, Hortaçsu, and Tintelnot (2019), as well as from policymakers and journalists, in part because it is one of the few categories of affected goods that coincides closely with a sectoral consumer price index (CPI) provided by the BLS, namely that for "Laundry Equipment." We obtain prices for about 700 washing machines from the private firm PriceStats as well as from the Billion Prices Project (BPP), which collected them by scraping, at a daily or weekly frequency, the online web pages of 16 large multi-channel retailers in the United States. ${ }^{15}$ See Cavallo and Rigobon (2016) for a full description of these and closely-related data.

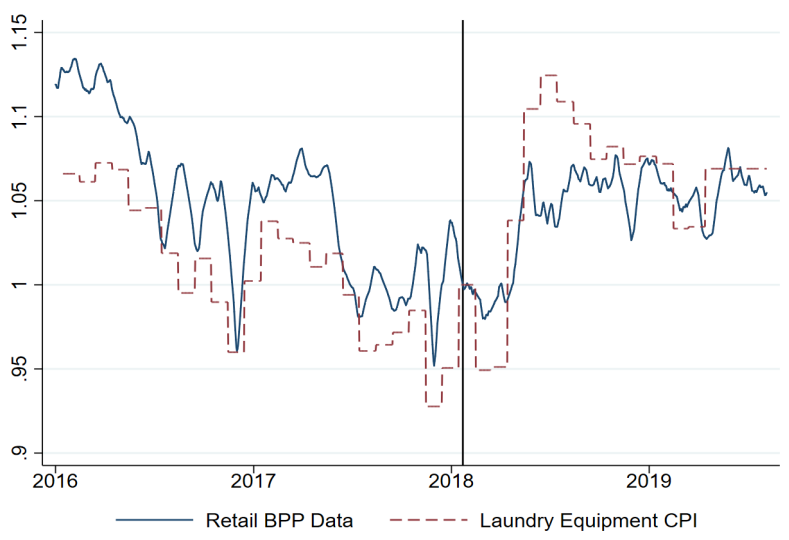

(a) Price Indices

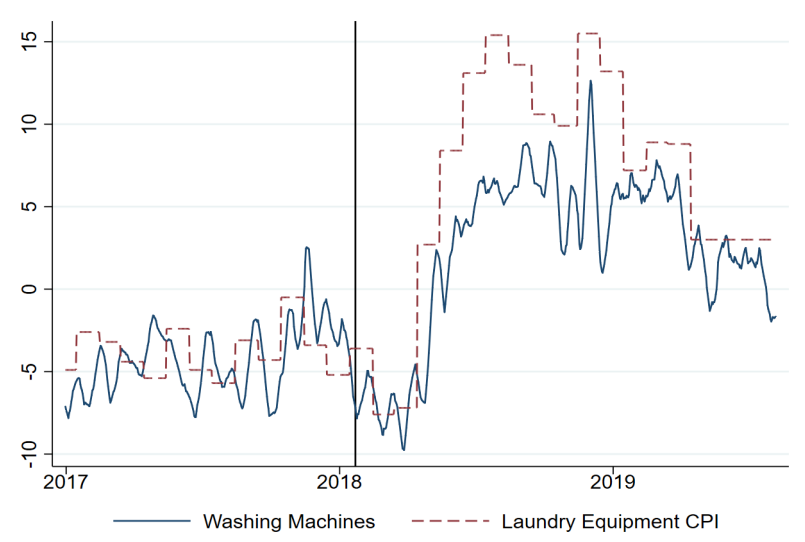

(b) Inflation Rates

Figure 4: Retail Washing Machine Prices from the BPP and the CPI

Figure 4(a) shows indices for these washing machine prices from the BPP data, calculated as

\footnotetext{
${ }^{15}$ Washing machines are defined as goods appearing in the data for at least one year, with product descriptions that include the words "washing machine" or "washer", and which exclude particular disqualifying words such as "washer fluid". As with our analyses of trade data, all our retail price analyses exclude adjacent prices that differ by more than $2.3 \log$ points in absolute value.
} 
an equally-weighted average of good-level price changes, as well from the CPI data. The price indices are normalized to equal 1 in February 2018, the month that tariffs were imposed, as indicated with a vertical black line. Figure 4(b) shows the annual inflation rates corresponding to these indices. Prior to the imposition of these tariffs, the BPP and CPI price indices for washing machines behaved similarly and declined by about 5 percent per year. Within a few months of the import tariffs, however, both series exhibit a break, with inflation rates switching from negative to positive values for both series. In the second half of 2018, washing machine inflation was typically between 5 and 10 percent in the BPP data and between 10 and 15 percent in the CPI data. This simple evidence strongly suggests moderate to high passthrough of the washing machine tariffs to retail prices.

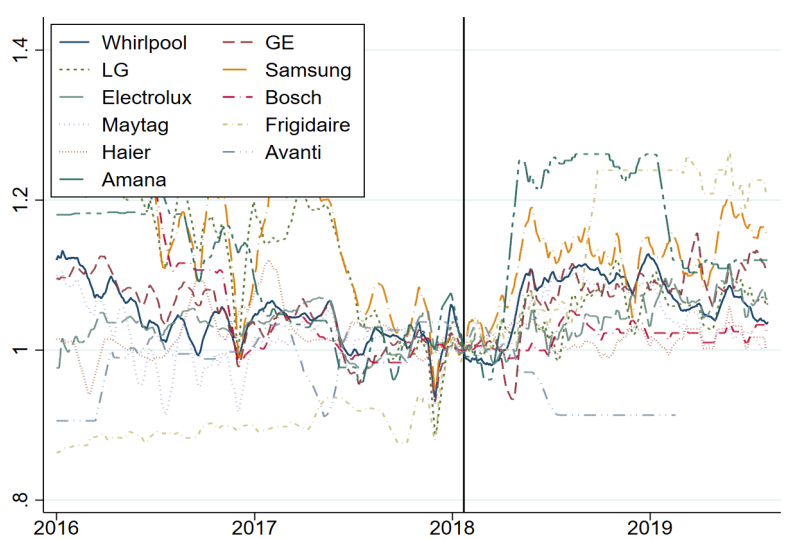

(a) Price Indices

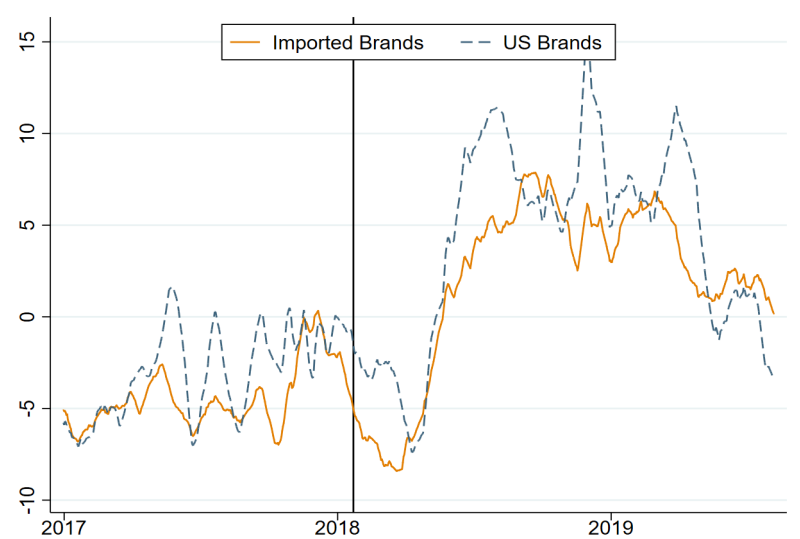

(b) Inflation Rates

Figure 5: Retail Washing Machine Prices from the BPP, Variation Across Brands

Underlying this high passthrough rate, however, is significant heterogeneity across different washing machine brands. Figure 5(a) plots the annual inflation rates brand-by-brand and shows that while the prices for Samsung washing machines clearly increased in response to the tariffs, the rate of inflation in Haier washers appears unchanged when comparing the pre- and post-tariff periods. It may be tempting to attribute such a heterogeneous response to heterogeneity in the tariff policies. Figure 5(b) demonstrates, however, that the basic pricing patterns look the same for US brands, which likely are not directly affected by the tariffs, and for imported brands, which likely are affected. ${ }^{16}$ Consistent with the conclusions in Flaaen, Hortaçsu, and Tintelnot

\footnotetext{
${ }^{16}$ We split these US brands (GE, Maytag, and Whirlpool) from the imported brands (Amana and Haier from China, Avanti from Denmark, Bosch from Germany, Frigidaire from Sweden, and LG and Samsung from South Korea) using online marketing reports, which may be imprecise for ascertaining the manufacturer's country of
} 
(2019), tariffs not only caused prices to increase for those washing machines that were affected, but also, led more generally to price hikes, including on products unaffected by the tariffs.

In the case of washing machine prices, the impact of tariffs is clear-cut, with high and rapid passthrough to retail prices. But how representative is this sector? Should we expect the same response in other sectors with large shares of products that are affected by the tariffs? To answer these questions, we next use data from the BPP and the CPI to consider the US retail prices of handbags, tires, refrigerators, and bicycles, all product categories that were significantly impacted by the tariffs on Chinese goods. ${ }^{17}$ The tariffs did not have as rapid or as obvious an impact on prices of these goods as was the case with washing machines.

Figure 6 shows the price indices and inflation rates for these four types of goods. As above, the plots include four vertical lines corresponding to the dates of tariff changes, and we normalize the prices to equal 1 in September of 2018 since the 10 percent tariffs introduced on that date were most relevant to this group of products. Unlike washing machines, none of these four goods exhibited sharp price increases relative to trend, even three months after the first tariffs were imposed. By the time the tariffs were increased to 25 percent, however, handbags and tires were experiencing unusually rapid price increases. Refrigerators exhibited a mild increase in inflation relative to the pre-tariff trend, but this increase appears to have started before the tariffs. Price inflation for bicycles has, if anything, decreased in the post-tariff regime.

This simple visual evidence on average price changes in these aggregated sectors suggest that import tariffs exhibited rapid and high passthrough to some sectors such as washing machines, slower but ultimately high passthrough to some sectors such as tires, and low passthrough to some sectors such as bicycles. To try to reach more precise conclusions, we now move to a retail dataset that allows us to compare the pricing behavior of goods that were originally sourced from China to those that were not.

origin. This is a useful example of the importance of analyses that use product-level information on the country of origin, which we turn to below.

${ }^{17}$ In addition to the common discussion of these products in media coverage of the tariffs, we chose these products because they are included in product descriptions in lists of harmonized codes that identify tariffs and in product descriptions appearing on retailers' web pages. We study 300 handbags from 12 retailers, 400 tires from 7 retailers, 5,000 refrigerators from 18 retailers, and 200 bicycles from 11 retailers. 


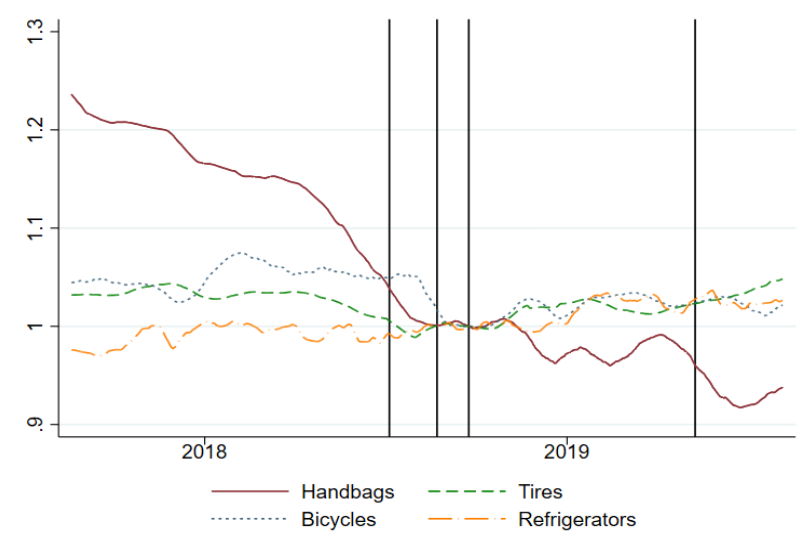

(a) Price Indices

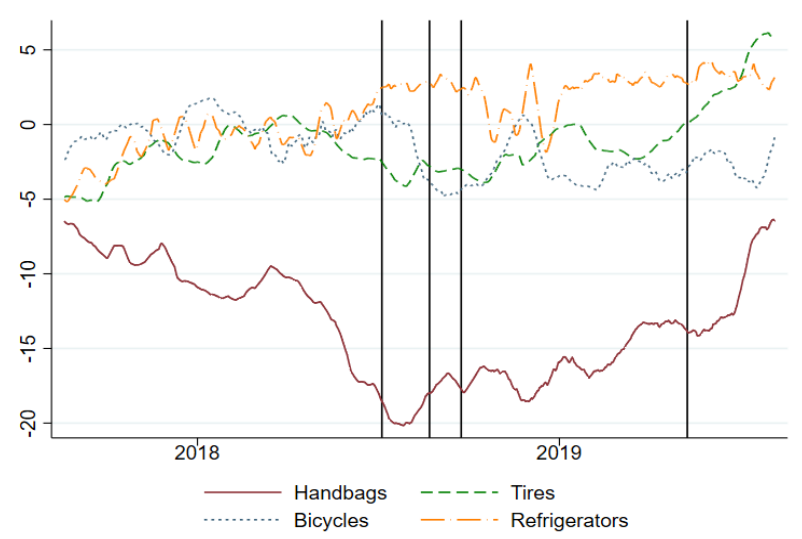

(b) Inflation Rates

Figure 6: Retail Prices from the BPP, Multiple Affected Goods

\subsection{Two Retailers with Country of Origin Information}

We now turn to data collected daily from two large US retailers, both in the top 10 in the United States in terms of revenues. For "Retailer 1", our data entirely reflects what could be obtained from scraping their webpages, including a description of each product as well as its country of origin. For "Retailer 2", we combine pricing data scraped off their web page with the country of origin, product sales rank, and a text product description which the retailer directly provided to us.

Given these data, the key challenge is to associate each product with an HS code so we can determine which are in categories affected by each wave of tariffs placed on China. We do this with a service provided by $3 \mathrm{CE}$ technologies (https://www.3ce.com), a private company that specializes in automated commodity classifications for trade purposes. ${ }^{18}$ In some cases, the $3 \mathrm{CE}$ algorithm is able to generate a mapping directly from the product description without any additional information. In other cases, we asked a group of research assistants to respond manually to the additional questions required by the $3 \mathrm{CE}$ algorithm to help refine its match, such as whether the product is portable or whether the product is a toy. ${ }^{19}$ Roughly three-quarters of

\footnotetext{
${ }^{18} 3 \mathrm{CE}$ provides similar online classification tools for the US Census (https://uscensus.prod.3ceonline.com/) and Eurostat (https://eurostat.prod.3ceonline.com/).

${ }^{19}$ Generally, these questions could easily be answered by looking at each product's page on the website of its retailer. When the requested information was not available online, we attempted to provide the most common or broadly representative answer possible. For example, if we were unable to answer a question about the material used to make a particular screw, we chose "steel" as that was the most common material used for screws when this information was provided. In cases where we could not visit the product's webpage because it was not longer offered for sale, we tried to locate the product on other retailer websites and searched for a close substitute. We commonly resorted to the latter strategy. For example, if we could not find a particular 4-pack of batteries, we would look for
} 
the total products then were classified automatically, with the remainder being done manually.

\begin{tabular}{|c|c|c|c|c|c|c|}
\hline & $\begin{array}{l}\text { Retailer } \\
1 \text { and } 2\end{array}$ & $\begin{array}{l}\text { Retailer } \\
1 \text { Only }\end{array}$ & $\begin{array}{l}\text { Retailer } \\
2 \text { Only }\end{array}$ & $\begin{array}{l}\text { Imported } \\
\text { Products }\end{array}$ & $\begin{array}{l}\text { Household } \\
\text { Products }\end{array}$ & $\begin{array}{l}\text { Electronics } \\
\text { Products }\end{array}$ \\
\hline Products & 92,624 & 37,840 & 54,784 & 59,978 & 64,421 & 10.891 \\
\hline Exporting Countries & 82 & 65 & 66 & 81 & 72 & 43 \\
\hline HS6 Categories & 1,991 & 1,651 & 831 & 1,498 & 1,406 & 781 \\
\hline Products Imported & 59,978 & 21,144 & 38,834 & 59,978 & 46,836 & 6,679 \\
\hline Products Imported from China & 43,490 & 13,646 & 29,844 & 43,490 & 35,748 & 3,566 \\
\hline Products in Affected Categories & 59,460 & 23,219 & 36,241 & 40,333 & 43,505 & 6,269 \\
\hline Products from China \& Affected & 30,101 & 8,757 & 21,344 & 30,101 & 25,212 & 1,954 \\
\hline \multicolumn{7}{|l|}{ Panel B: Pricing Behavior } \\
\hline Products Without Price Changes (\%) & 42 & 49 & 37 & 47 & 43 & 43 \\
\hline Mean Product Life (months) & 18 & 16 & 19 & 1818 & 15 & \\
\hline Abs. Val. Price Changes (med., \%) & 11.1 & 14.3 & 10.0 & 11.4 & 10.8 & 11.9 \\
\hline Abs. Val. Price Changes, Ex-Sales (med., \%) & 9.9 & 11.4 & 8.9 & 10.0 & 9.7 & 10.0 \\
\hline Implied Duration (med., months) & 8.9 & 9.7 & 8.5 & 9.7 & 8.5 & 6.9 \\
\hline Implied Duration, Ex-Sales (med., months) & 10.5 & 12.7 & 9.5 & 11.2 & 11.1 & 8.4 \\
\hline
\end{tabular}

Table 3: Summary Statistics from Two Major US Retailers

Panel A of Table 3 summarizes the resulting dataset. Our data include about 38,000 products from Retailer 1. For Retailer 2, we matched the scraped price data to the top 100,000 products by sales rank, leaving about 55,000 products. Combined, the data include more than 90,000 products covering nearly 2000 different 6-digit HS categories. Roughly two-thirds of the products, about 60,000, are imported from one of more than 80 countries. About 43,000 products are imported from China, with 30,000 of them in categories affected by the tariffs. Importantly for our purposes, there is significant and somewhat evenly distributed coverage across goods that are or are not in affected categories and that are or are not sourced from China. ${ }^{20}$

Since our analyses focus on price changes in these data, Panel B of Table 3 offers some basic summary statistics characterizing the dynamic pricing behavior of these goods. Retailer 1 has slightly stickier prices, with median price spells lasting 9.7 months, and 49 percent of products never experiencing a price change compared to corresponding respective values of 8.5 months and 37 percent for Retailer 2. Broadly, however, the two retailers exhibit similar pricing patterns. The final two columns in the table report statistics for those products that are imported, that identical batteries sold by the same retailer in a 6 -pack.

${ }^{20}$ The share of Chinese goods may not be representative of the total sales made by these retailers. 
are household products, and that are electronics products. $^{21}$

We start by using these data to plot daily retail price indices and corresponding annual retail inflation rates separately for those products imported from China that were affected by the tariffs, products imported from China that were unaffected, products not imported from China but in categories that were affected, and products not imported from China and in categories that were not affected, equivalent to the import data shown in Figure 1. Looking at the price indices in Figure 7(a), or the inflation rates in Figure 7(b), it is difficult to discern any quantitatively important price differences brought about by the tariffs. The inflation rates in all groups behave similarly, though the exception may be unaffected products sold by China, as this goods sector exhibited the largest increase in inflation rates over the sample period.

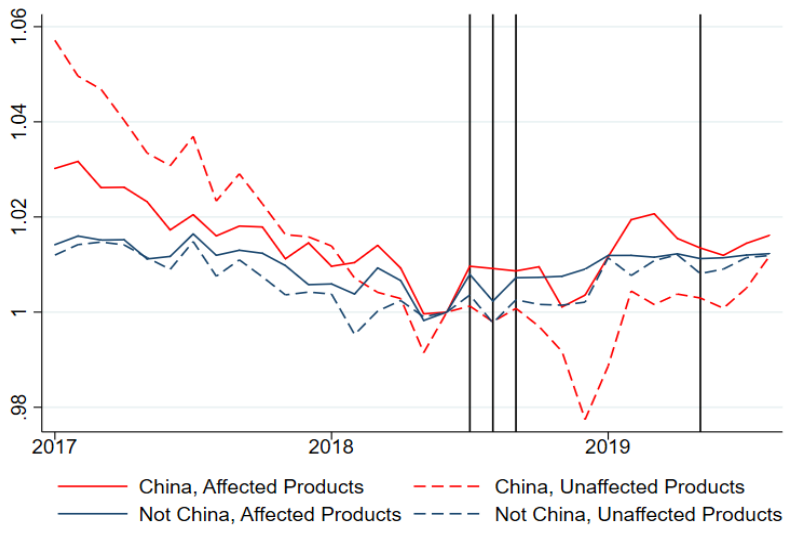

(a) Price Indices

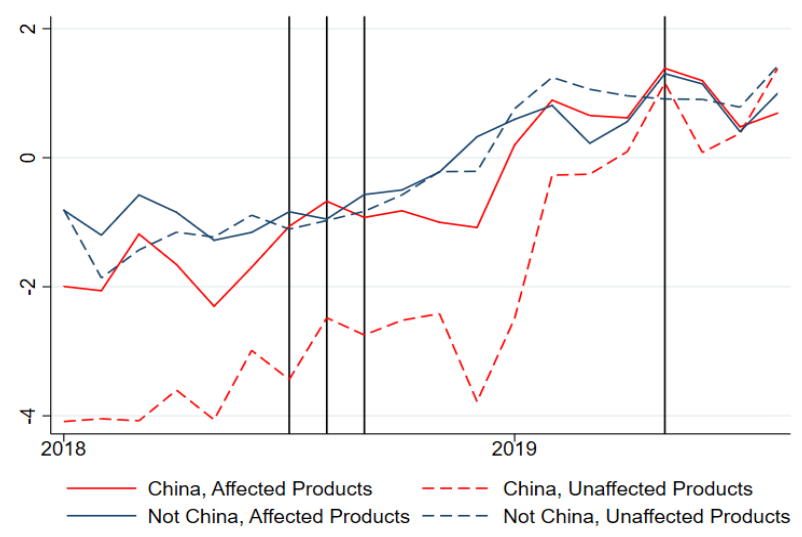

(b) Inflation Rates

Figure 7: Retail Price Response to Chinese Import Tariffs by Two US Retailers

To more precisely identify the differential retail pricing behavior of products impacted by the tariffs, we now use these data to estimate at a monthly frequency a regression specification similar to equation (2) used in our analysis of import prices. We regress the change in retail prices on current and lagged tariff changes, plus fixed effects allowing for different price trends per sector and additionally different trends for the total sets of Chinese products that are and

\footnotetext{
${ }^{21}$ Household products are those with a 3-digit Classification of Individual Consumption According to Purpose (COICOP) starting with a "5", and electronics products are those with a 3-digit COICOP beginning with a "9". A given HS6 can occasionally contain both kinds of COICOPs, so some HS6 categories can have both Household and Electronics products in them. Table 3 includes some "Ex-Sales" statistics, which remove temporary price changes identified using the "Filter A" sales algorithm introduced in Nakamura and Steinsson (2008).
} 
are not affected by the tariffs:

$$
\Delta \ln \left(P_{i, j, k, t}^{\mathcal{R}}\right)=\delta_{k}^{\mathcal{R}}+\phi_{\mathrm{CN}}^{\mathcal{R}, \Omega}+\phi_{\mathrm{CN}}^{\mathcal{R},-\Omega}+\sum_{l=0}^{9} \gamma_{\mathrm{CN}, l}^{\mathcal{R}} \Delta \tau_{\mathrm{CN}, k, t-l}+\epsilon_{i, j, k, t},
$$

where now the sectors $k$ are defined as 3-digit COICOP codes and where we no longer include information on producer prices nor on exchange rates. The results, reported in Table 4, show that while the prices for products affected by the Chinese import tariffs grow relative to the price of products in the same sector that were not affected, the difference is not stark.

The first column estimates the regression using monthly data from both retailers for the time period running from January 2017 to July 2019. In the top row, the coefficient of 0.044 means that after one year, a 10 percentage point tariff increase on a good is associated with a 0.44 percent increase in that good's price relative to other goods in the same sector. This estimate increases slightly, but is very similar, if we separately analyze the prices of each of the two retailers or only estimate the results for imported products (i.e. excluding those with the United States as the country of origin). When we separate products by their type, we obtain an estimate of 0.045 for household products and 0.070 for electronics products. ${ }^{22}$

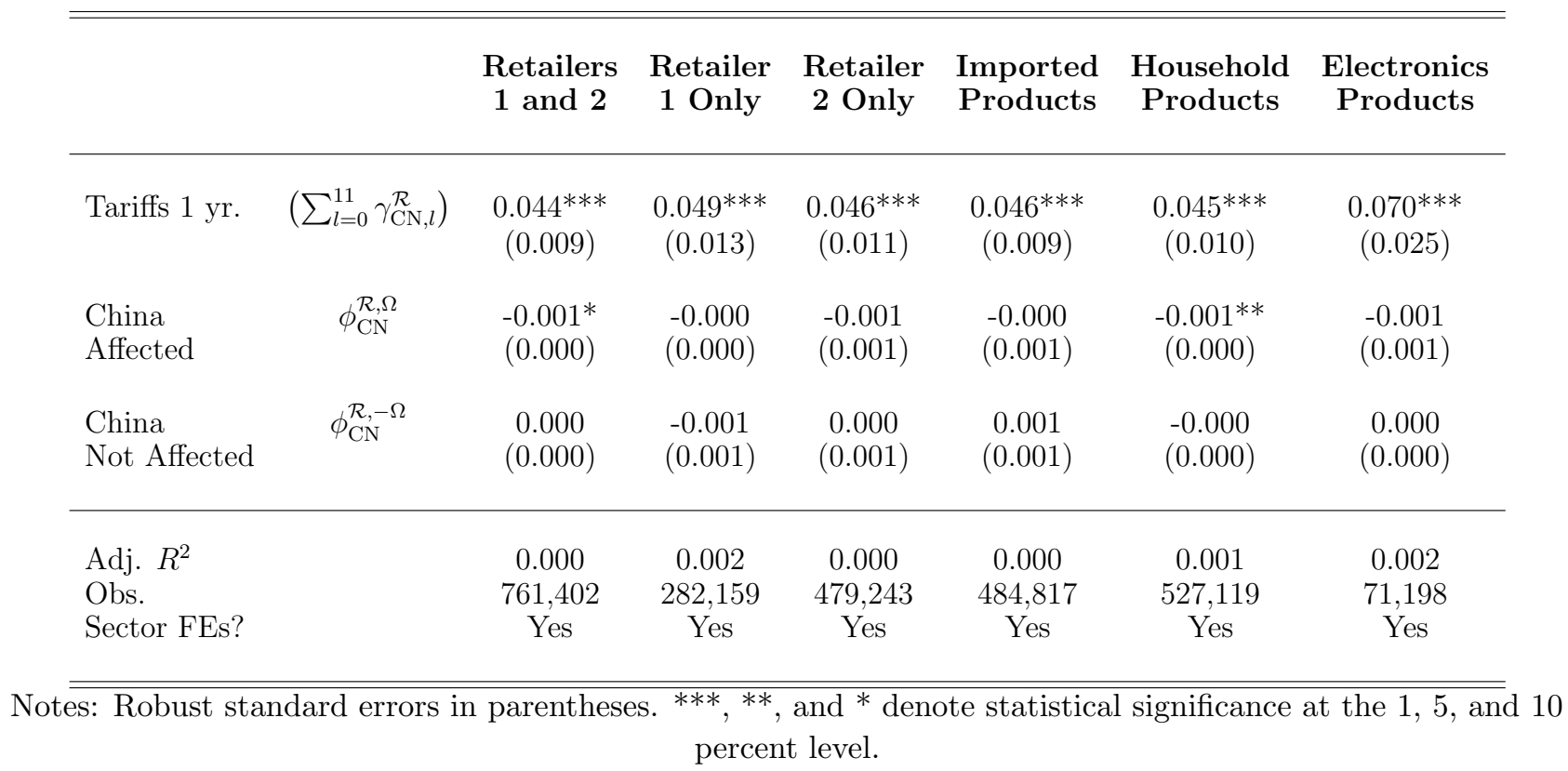

Table 4: Regression Analysis of US Retail Prices

One might reasonably worry that measurement error in the sectoral classification algorithm

\footnotetext{
${ }^{22}$ If we additionally include time (i.e. month) dummies, the estimates for price increases after one year go up a bit to 0.057 for all products, 0.063 for household products, and 0.073 for electronics products.
} 
is limiting our ability to identify larger differences in the retail price dynamics between products affected and unaffected by the tariffs. Incorrectly classifying affected products as belonging to HS codes that are not affected by the tariffs, or the reverse, would by construction bias the analysis by making the groups more similar. To look for evidence of this, we consider two subsets of our data that are the least likely to contain sectoral classification errors. First, we exploit the fact that about one-quarter of the products were matched manually, requiring a research assistant to affirmatively check the association of a product's text description with the HS classification. Second, we obtained a list of products that were directly imported by Retailer 2, rather than purchased through an importer or wholesaler, so we can be confident that the retailer's perception of the HS code is the relevant one. The regressions run on these two subsets of the data do not have as much power as the full sample, but also do not expose large differences between the affected and unaffected groups.

\subsection{International Comparisons: Evidence from Canada}

Section 3.1 demonstrated that the total cost of imports has increased roughly one-for-one with the tariffs. We have shown that some sectors heavily affected by the tariffs - including washing machines, handbags, and tires - appear to have passed these costs through into retail prices. Other goods sectors, however, such as bicycles and refrigerators, exhibit little obvious signs of tariff passthrough, and our regression analysis of nearly 100,000 products suggested that in response to a 20 percent tariff, the price of a typical affected import from China has only increased by about 1 percent relative to unaffected products in the same sector after one year. Assuming that the total cost of an imported good (inclusive of tariffs) accounts for half of the retailer's marginal cost for that good, a 20 percent tariff would require a far larger retail price hike to avoid a reduction in retail margins. ${ }^{23}$

An alternative possibility is that retailers increased their margins on unaffected goods to partially offset the margin reduction on affected goods, muting any changes in their overall margins. Or, consistent with the results in Figure 5(b), perhaps tariffs enabled the producers of unaffected goods to raise their markups. Both of these cases would stabilize the relative prices of affected and unaffected products within narrowly defined sectors. Rather than inferring the

\footnotetext{
${ }^{23}$ See DArcy, Norman, Shan, et al. (2012) for typical examples of the cost shares in retailers' operating structure, which are in line with this back-of-the-envelope calculation.
} 
impact of tariffs by comparing the prices of affected and unaffected goods within sectors, in these cases we would expect to see the prices in affected US sectors rise (compared to the overall CPI) relative to the prices in countries that did not impose tariffs on these goods.

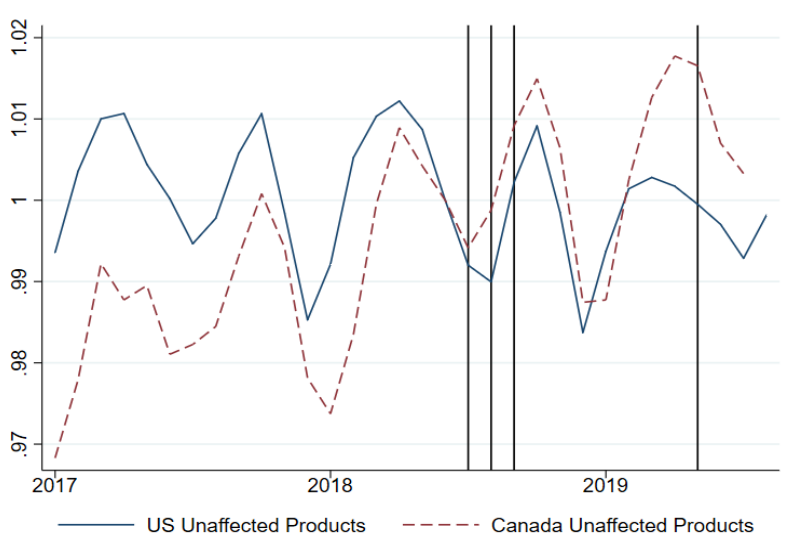

(a) Unaffected Sectors

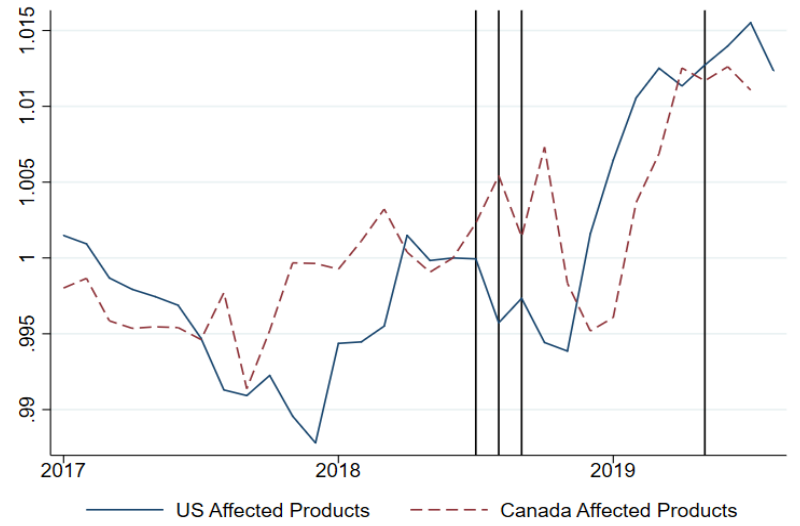

(b) Affected Sectors

Figure 8: Retail Prices for the United States and Canada, Data from CPI

To consider these possibilities, in Figure 8 we start by comparing the sector-level price indices for affected and unaffected sectors underlying "Commodities less food and energy" in the United States and "Goods excluding food purchased from stores and energy" in Canada, data publicly available from the US Bureau of Labor Statistics and Statistics Canada. ${ }^{24}$ Figure 8(a) shows the price indices for those sectors unaffected by tariffs. Before mid-2018, Canada's unaffected sectors had a higher inflation rate, though the price indices for unaffected sectors in the United States and Canada are both essentially flat after the imposition of the tariffs. Figure 8(b) then compares the price indices constructed for sectors affected by the tariffs. While starting with the imposition of the tariffs, there does appear to be a moderate increase in inflation among affected categories in the United States, interestingly, this also appears to be the case in Canada, though to a lesser degree. ${ }^{25}$

Figure 8 suggests that at least some of the price increases in the affected goods sectors may not truly reflect the tariffs, or may only reflect the general equilibrium effects of tariffs, since

\footnotetext{
${ }^{24}$ Based on the share of trade in the categories that is covered by the tariffs, we designate the following nine CPI sectors as "affected": Furniture and bedding, Laundry equipment, Miscellaneous personal goods, Motor vehicle parts and equipment, Personal care products, Pets and pet products, Sewing machines, fabric and supplies, Sports vehicles including bicycles, and Tools, hardware, outdoor equipment and supplies. The remaining sectors are designated as "unaffected". We then do our best to manually match these sectors for Canada. We use price indices that are not seasonally adjusted because some of these series for Canada are not available with seasonal adjustments.

${ }^{25}$ This analysis for the United States is reminiscent of, and largely consistent with, a widely distributed report by Goldman Sachs (2019).
} 
Canada has not imposed tariffs on imports from China. We note, however, that this analysis is highly imperfect and has limited power. The affected sectors are not chosen based on trade as a share of expenditures and do not distinguish trade from China and from other countries. Furthermore, the sectors are defined differently across the two countries, and even when the matching of sectors is good in concept, the two countries may consume very different products in practice. To avoid these issues, we next compare the prices for identical goods sold by Retailer 2 in the United States and in Canada.

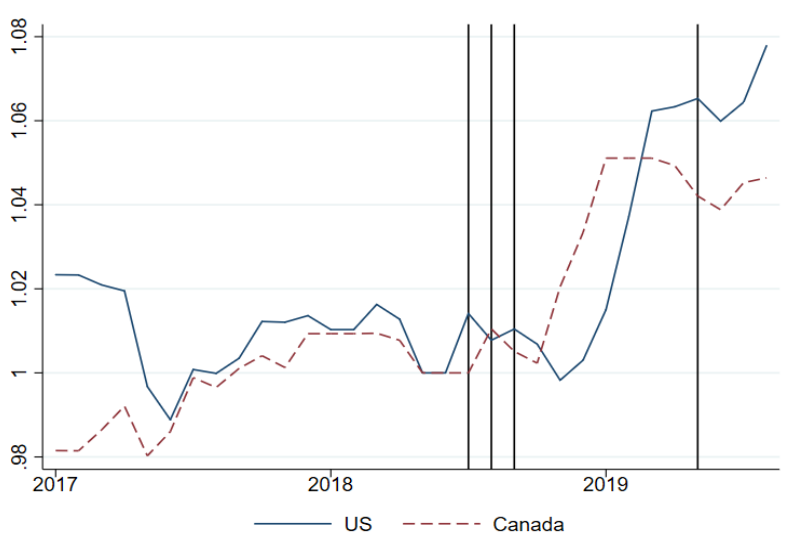

(a) Price Indices

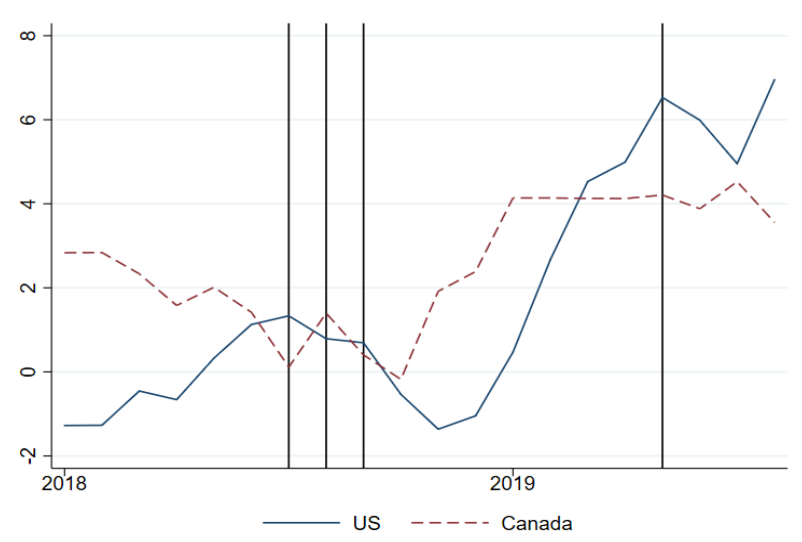

(b) Inflation Rates

Figure 9: US and Canadian Retail Prices from Retailer 2

We identify 2,436 products that are sold by Retailer 2 in both the United States and Canada and plot the price indices and inflation rates separately for each country, using only the retail prices for those common goods in Figure $9 .{ }^{26}$ Given that the overall CPIs for the United States and Canada evolved similarly over this period, the two panels do not suggest any particularly unusual dynamics in the US prices for these goods relative to the Canadian goods over the period when the tariffs were imposed.

The patterns in Figure 9, of course, only reflect data from a single retailer. While we could not match identical goods sold in the United States and Canada for more retailers, we added pricing data for sales in the two countries for six additional retailers that operate in those two countries and sell home goods, electronics, apparel, and furniture, including two other top-10 US retailers.

\footnotetext{
${ }^{26}$ We identify identical products by looking for an exact match in model numbers, requiring that the model numbers have at least five characters. The model numbers are typically determined by the product manufacturers. They often will be identical other than the last two characters, which will be "us" or "ca". We do not consider such cases to be identical products and exclude them. In total, the matched products cover 19 3-digit COICOP categories and are largely furniture products, household appliances, tools and equipment, and home repair items. We note that we did not require these goods to be available during the identical time spans in each country.
} 


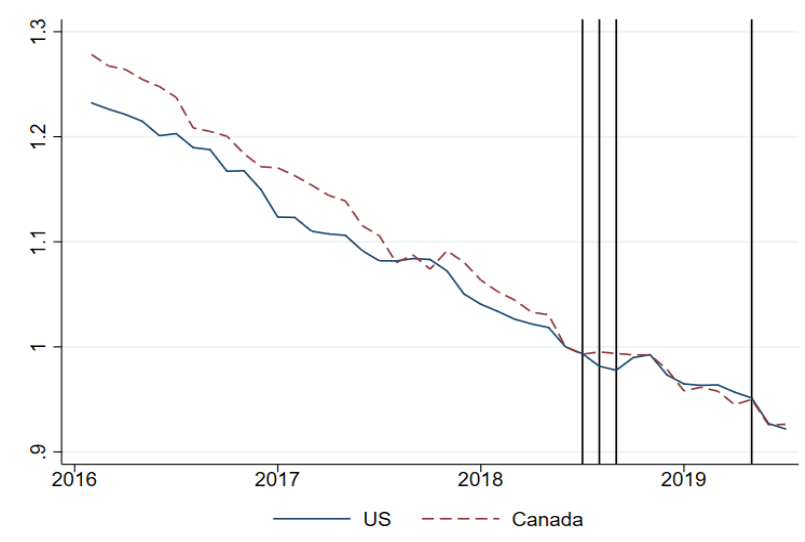

(a) Price Indices

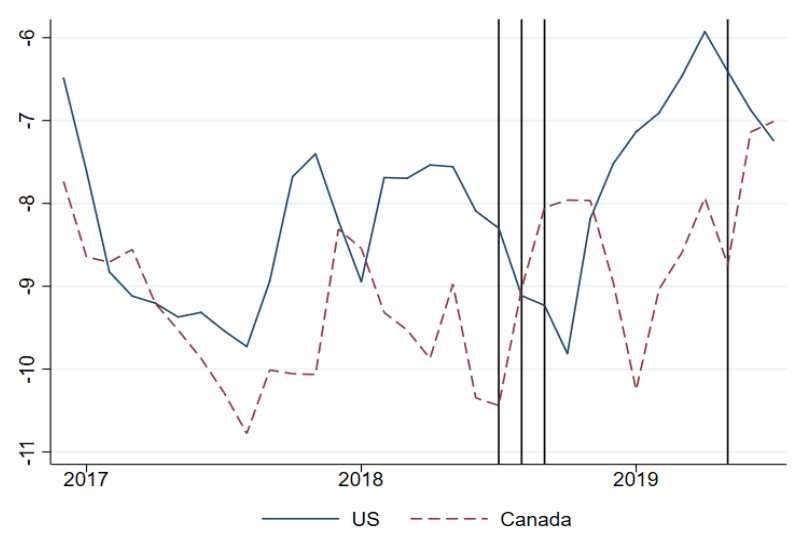

(b) Inflation Rates

Figure 10: US and Canadian Retail Prices, Multiple Retailers

We selected 43 3-digit product categories and created price indices for each category, country, and retailer. ${ }^{27}$ We then use equal weights for each retailer and the same average sectoral expenditure weights for both countries to generate US and Canadian price indices for these goods, where any differences can be thought of as reflecting within-retailer and within-category differences in inflation across the two countries. The results, plotted in Figure 10, again do not obviously reveal that retailers raised prices for their US customers relative to their Canadian customers, even for the same set of goods. We conclude that retailer profit margins absorbed at least a moderate amount of the adjustment to the import tariffs. ${ }^{28}$

\subsection{Other Adjustment Margins: Front-Running and Trade Diversion}

Given the nearly-complete passthrough of tariffs to the prices of US imports from China and the relatively modest impact of those goods on consumer prices, retailer profit margins likely declined. In this subsection, we demonstrate two other margins along which retailers adjusted in response to the tariffs. First, we demonstrate that after the tariffs were announced and early in the first tariff regime, our two US retailers increased their volume of imports from China, perhaps in efforts to front-run the tariffs and build inventories of key products impacted by the

\footnotetext{
${ }^{27}$ We used prices for about 350,000 products in the United States and about 120,000 in Canada.

${ }^{28}$ We note that while we observe very high passthrough of tariffs to the import price at the economy-level, our retail results largely reflect prices set by the largest firms. It is possible that in terms of their negotiating power as buyers, these giant retailers differ from the average retailer and this difference may contribute to our finding of surprisingly modest passthrough to their retail prices. When we restrict our analysis of import tariffs on Chinese goods to firms with two or more subdivisions reporting to the BLS - a proxy for large firms - the estimate corresponding to "Tariffs 1 yr." in column (4) of Table 1 decreases to -0.112 and is statistically significant at the 10 percent level.
} 
tariffs before prices went up. Second, we show that whereas they imported almost entirely from China prior to the tariffs, they started diverting some of their orders to other countries once the tariffs were put in place.

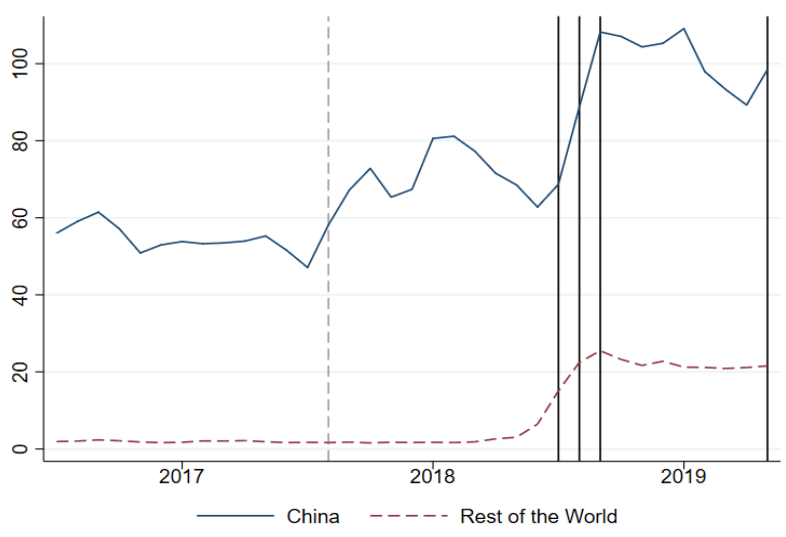

(a) Tons Imported, Thousands

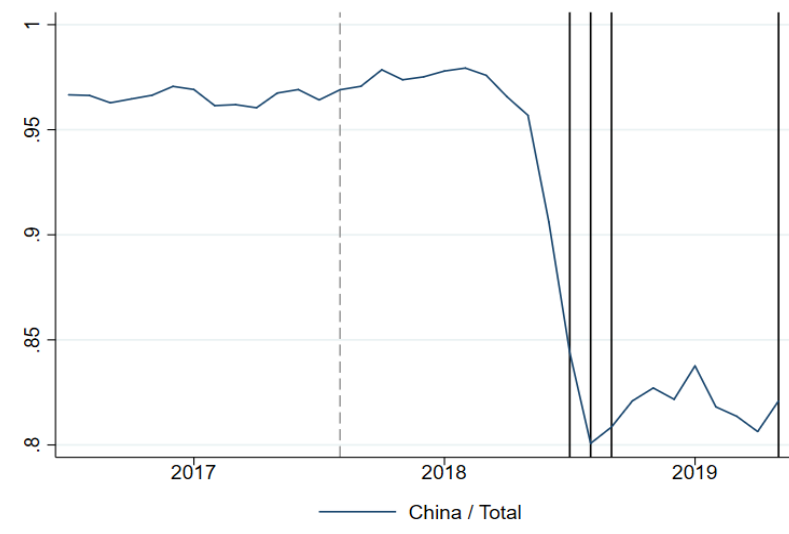

(b) Share of Tons Imported from China

Figure 11: Front-Running and Trade Diversion by Two Major US Retailers

In order to study the importing behavior of our two retailers, we make use of data provided by Datamyne, a private vendor of trade intelligence that collects maritime bills of lading. ${ }^{29}$ We add together the tonnage imported each month by these companies and plot, in Figure 11(a), a 3-month moving average of the tonnage ordered from China and from the Rest of the World. The solid blue line, showing tonnage (in thousands) imported from China, is around 55,000 tons and remains relatively flat from the third quarter of 2016 through the second quarter of 2017, but appears to jump in August 2017, the date indicated with the dashed vertical line. The vertical line is dashed rather than solid to indicate that the US Trade Representative was directed at that date to determine whether to initiate a Section 301 investigation against China (and shortly thereafter did initiate the investigation). Imports appear to have increased roughly 20 percent at that point, presumably as firms wished to import supplies prior to the actual imposition of any tariffs. When tariffs were in fact announced, imports jumped further, before declining a bit thereafter (though by early 2019, still at elevated levels). Many of these goods were likely affected by the 10 percent tariff rate, and the importers may have wanted to stockpile them before the announced 25 percent tariffs on those same goods was instituted.

\footnotetext{
${ }^{29}$ We can query keywords in the data and identify our two retailers by searching for bills of lading containing their names in any field.
} 
Furthermore, Figure 11(a) shows that when the tariffs were introduced, these retailers first started importing non-trivial quantities from countries other than China. From a near-zero level, the red dashed line rises above 20,000 tons per month. As summarized in Figure 11(b), China's share of these firms' total imports was about 97 percent prior to the tariffs, then declined to about 80 percent since the late summer of 2018. The results for Figure 11 would be very similar if we plotted shipping containers or value instead of tons. Our two importers clearly engaged in some front-running behavior ahead of the tariffs and also were able to adjust in part by shifting to other countries as suppliers. ${ }^{30}$

\section{$5 \quad$ US Exports}

In response to the US trade policies enacted in 2018, many countries - including Canada, China, the EU, and Mexico - imposed retaliatory measures on the United States. As discussed above, the stability of ex-tariff prices set by foreign exporters to the United States led us to conclude that much of the price incidence of US import tariffs is borne by the United States. In this final section, we use data on these retaliatory tariffs from the International Trade Administration website to study the stability of ex-tariff prices set by US exporters to foreign destinations. Interestingly, unlike the case of foreign exporters, we do find evidence that US exporters have significantly reduced their prices in response to the foreign tariffs. The fact that we do see declines in the ex-tariff export prices of targeted US products suggests that the retaliatory tariffs imposed on the United States have meaningful incidence in the United States as well.

Figure 12 plots the ex-tariff prices of US exports affected and unaffected by recently imposed foreign tariffs. The vertical lines in this figure correspond to the dates on which different countries either initiated or increased their retaliatory tariffs on US exports. ${ }^{31}$ Of course, the affected goods are different types of goods, and exhibit greater price volatility even before the trade wars began. Nonetheless, the post-tariff period represents the first time when the price indices for the two types of goods move so differently, with the prices of unaffected goods highly stable and the prices of affected goods dropping by about 7 percent.

\footnotetext{
${ }^{30}$ These two retailers are large firms that might have more working capital and an easier time importing goods to build up inventories. An open question is the extent to which this pattern applies to the rest of the US retail sector.

${ }^{31}$ China was the first to initiate tariffs on US products in April 2018 and expanded their tariffs in July, August, and September. The European Union, Mexico, and Turkey initiated tariffs on US goods in June 2018, followed by Canada in July 2018, Russia in August 2018, and India in June 2019.
} 


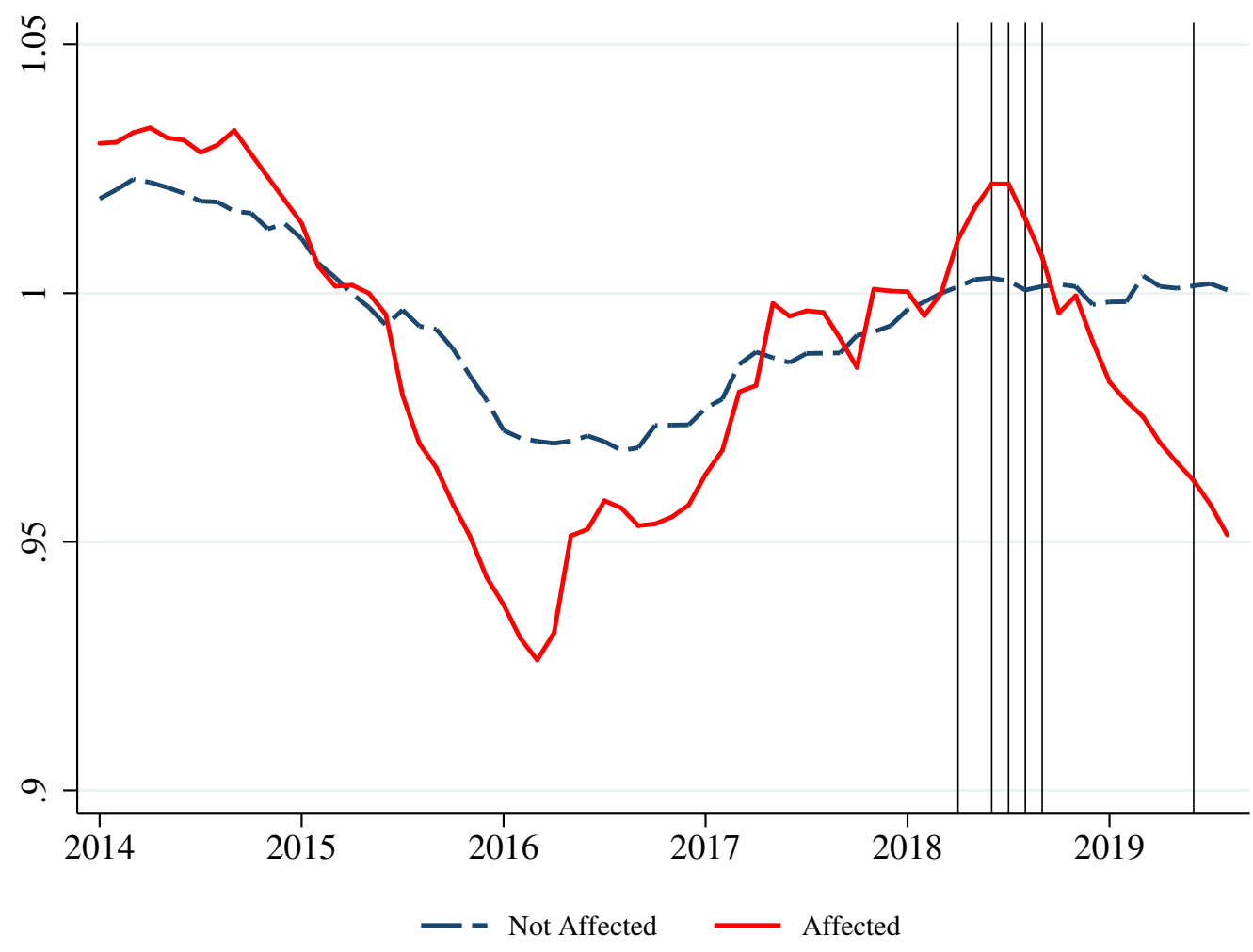

Figure 12: US Export Price Indices for Goods Affected and Not Affected by Foreign Tariffs

Why did US exporters drop their prices so much more when faced with foreign tariffs than foreign exporters did when faced with US tariffs? Differences in the types of goods affected by the trade policy played a key role. We use the Rauch (1999) classification to identify differentiated goods, for which substitutes are likely more difficult to locate, and find that they account for more than 90 percent of the affected imports to the United States from China but less than half of the US exports to countries that imposed retaliatory tariffs. Relatedly, whereas affected US imports were rarely agricultural goods - goods often thought of as non-differentiated - US agriculture products accounted for roughly 10 percent of affected US exports in our sample. If undifferentiated goods are those for which import tariffs generate ex-tariff price differences, this might explain why US imports saw little or no ex-tariff price declines, while US exports suffered moderate ex-tariff price declines. Indeed, Figures 13(a) and 13(b) demonstrate that, in an accounting sense, undifferentiated goods and agricultural goods are those products driving the decline in US export prices.

To elaborate on these findings, we now consider two types of regression specifications to study 


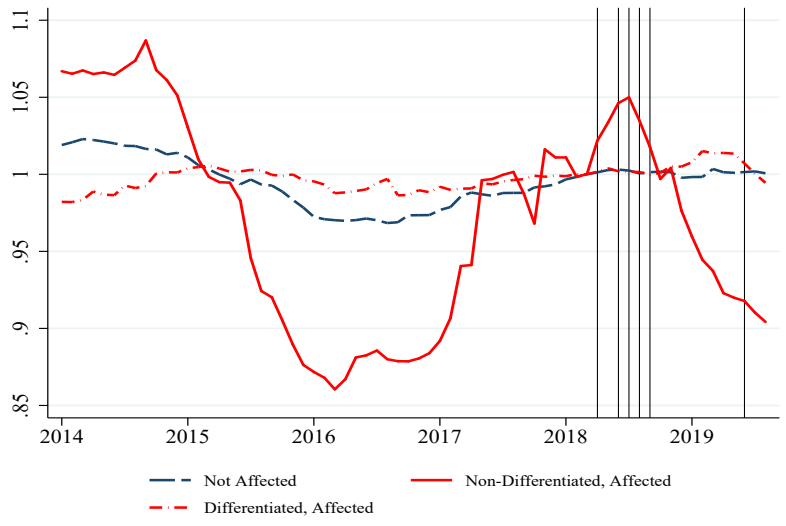

(a) Differentiated and Non-Differentiated Goods

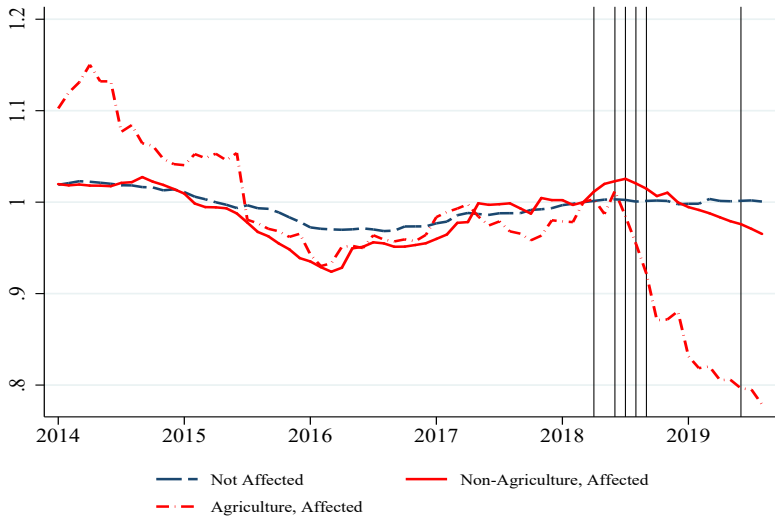

(b) Agricultural and Non-Agricultural Goods

Figure 13: Decomposition of US Export Price Indices

US exports, analogous to what we did for the case of US imports. Our preliminary regression analysis of the first specification is consistent with the visual conclusion reached from Figure 12. Specifically, we start by running the following equation with all monthly observations, including periods in which there is no price change:

$$
\Delta \ln \left(P_{i, j, k, t}^{\mathcal{E}}\right)=\delta_{k}^{\mathcal{E}}+\sum_{l=0}^{11} \gamma_{l}^{\mathcal{E}} \Delta \tau_{k, t-l}+\sum_{l=0}^{11} \beta_{l}^{\mathcal{E}, S} \Delta \ln \left(S_{j, t-l}\right)+\sum_{l=0}^{11} \beta_{l}^{\mathcal{E}, X} \Delta \ln \left(X_{j, t-l}\right)+\epsilon_{i, j, k, t}(5)
$$

where we now use the superscript $\mathcal{E}$ to denote that the data and the relationships in equation (5) correspond to US exports.

Table 5 reports the results from estimating (5) on monthly data. As shown in column (1) there is about a 54 percent passthrough of the retaliatory tariff into ex-tariff US export prices after 12 months. That is, a 10 percent tariff imposed on US exports reduces US ex-tariff export prices by about 5.4 percent. The estimate reduces to 4.8 percent when controlling for other pricedetermining factors, as seen in column (4). The cumulative one-year ERPT estimates are close to 20 percent. This estimate is little changed when we simultaneously include tariff measures as a covariate. Retaliation from China accounts for about three-quarters of our observations, so in column (5), we separately estimate the one-year cumulative effect of the retaliatory tariffs for US goods exported to China and for US goods exported elsewhere. Whereas shipments to countries other than China show no statistically significant decline in the ex-tariff export price, the effect is very strong when estimated separately for China, with an estimated one-year ex-tariff export price decline of about 63 percent. 


\begin{tabular}{|c|c|c|c|c|c|c|}
\hline & & (1) & $(2)$ & $(3)$ & $(4)$ & $(5)$ \\
\hline Tariffs 1 yr. & $\left(\sum_{l=0}^{11} \gamma_{l}^{\mathcal{E}}\right)$ & $\begin{array}{c}-0.541^{* * *} \\
(0.107)\end{array}$ & $\begin{array}{c}-0.525^{* * *} \\
(0.111)\end{array}$ & & $\begin{array}{c}-0.481^{* * *} \\
(0.111)\end{array}$ & \\
\hline China Tariffs 1 yr. & $\left(\sum_{l=0}^{11} \gamma_{l}^{\mathcal{E}, \mathrm{CN}}\right)$ & & & & & $\begin{array}{c}-0.628^{* * *} \\
(0.152)\end{array}$ \\
\hline Non-China Tariffs 1 yr. & $\left(\sum_{l=0}^{11} \gamma_{l}^{\mathcal{E},-\mathrm{CN}}\right)$ & & & & & $\begin{array}{c}0.064 \\
(0.115)\end{array}$ \\
\hline ERPT 1 yr. & $\left(\sum_{l=0}^{11} \beta_{l}^{\mathcal{E}, S}\right)$ & & & $\begin{array}{c}0.188^{* * *} \\
(0.018)\end{array}$ & $\begin{array}{c}0.187^{* * * *} \\
(0.018)\end{array}$ & $\begin{array}{c}0.187^{* * *} \\
(0.018)\end{array}$ \\
\hline PPI PT 1 yr. & $\left(\sum_{l=0}^{11} \beta_{l}^{\mathcal{E}, X}\right)$ & & & $\begin{array}{c}0.239 * * * \\
(0.040)\end{array}$ & $\begin{array}{c}0.238^{* * *} \\
(0.040)\end{array}$ & $\begin{array}{c}0.235^{* * *} \\
(0.039)\end{array}$ \\
\hline & $\begin{array}{l}\text { Adj. } R^{2} \\
\text { Obs. } \\
\text { Sector FEs? }\end{array}$ & $\begin{array}{c}0.000 \\
433,664 \\
\text { No }\end{array}$ & $\begin{array}{c}0.001 \\
433,664 \\
\text { Yes }\end{array}$ & $\begin{array}{c}0.002 \\
433,664 \\
\text { Yes }\end{array}$ & $\begin{array}{c}0.002 \\
433,664 \\
\text { Yes }\end{array}$ & $\begin{array}{c}0.002 \\
433,664 \\
\text { Yes }\end{array}$ \\
\hline
\end{tabular}

Notes: Robust standard errors in parentheses. ${ }^{* * *},{ }^{* *}$, and ${ }^{*}$ denote statistical significance at the 1,5 , and 10 percent level.

Table 5: Regression Analysis of Retaliatory US Export Tariffs, Monthly Data

As we did in Section 3.1 for imports, here we also consider a second specification that only includes non-zero price changes. We define $\left\{t_{0}, t_{1}\right\}$ as above, estimate the following:

$$
\begin{aligned}
\frac{1}{t_{1}-t_{0}} \ln \left(\frac{P_{i, j, k, t_{1}}^{\mathcal{E}}}{P_{i, j, k, t_{0}}^{\mathcal{E}}}\right) & =\delta_{k}^{\mathcal{E}}+\gamma^{\mathcal{E}} \tau_{k, t_{1}}+\beta^{\mathcal{E}, S} \frac{1}{t_{1}-t_{0}} \ln \left(\frac{S_{j, t_{1}}}{S_{j, t_{0}}}\right) \\
& +\beta^{\mathcal{E}, X} \frac{1}{t_{1}-t_{0}} \ln \left(\frac{X_{j, t_{1}}}{X_{j, t_{0}}}\right)+\epsilon_{i, j, k, t_{1}, t_{0}},
\end{aligned}
$$

and report our results in Table 6. Here, our estimates of exchange rate passthrough rise to about 36 percent, similar to the results from import regressions conditional on a price change, as reported in Table 2. As in Table 2, we multiply the magnitude of the coefficient on tariff passthrough by 12 in order to annualize the estimates. All the estimated effects of the tariffs shown in the first row are large in magnitude and statistically significant, and column (5) makes it clear that US exports to China underlie the results. As before, we note that in comparison to the results presented in Table 5, it is not surprising that the magnitudes of these results are larger since these condition on a price change and exclude observations where the left-hand-side is zero. 
We conclude from Figures 12-13 and Tables 5-6 that the retaliatory tariffs applied to US exports exhibited significantly lower passthrough than was the case for the US tariffs on imports, in large part because the US exports that were retaliated against were less differentiated compared to the goods targeted by US import tariffs.

\begin{tabular}{|c|c|c|c|c|c|c|}
\hline & & (1) & $(2)$ & (3) & (4) & $(5)$ \\
\hline $\begin{array}{l}\text { Tariffs } \\
\text { (Annualized) }\end{array}$ & $12 \times \gamma^{\mathcal{E}}$ & $\begin{array}{c}-0.876^{* * *} \\
(0.164)\end{array}$ & $\begin{array}{c}-0.919^{* * *} \\
(0.170)\end{array}$ & & $\begin{array}{c}-0.793^{* * *} \\
(0.168)\end{array}$ & \\
\hline $\begin{array}{l}\text { China Tariffs } \\
\text { (Annualized) }\end{array}$ & $12 \times \gamma^{\mathcal{E}, \mathrm{CN}}$ & & & & & $\begin{array}{c}-0.993^{*} \\
(0.201)\end{array}$ \\
\hline $\begin{array}{l}\text { Non-China Tariffs } \\
\text { (Annualized) }\end{array}$ & $12 \times \gamma^{\mathcal{E},-\mathrm{CN}}$ & & & & & $\begin{array}{c}0.405 \\
(0.320)\end{array}$ \\
\hline ERPT & $\beta^{\mathcal{E}, S}$ & & & $\begin{array}{c}0.362^{* * *} \\
(0.029)\end{array}$ & $\begin{array}{c}0.360^{* * *} \\
(0.029)\end{array}$ & $\begin{array}{c}0.361^{* * *} \\
(0.029)\end{array}$ \\
\hline \multirow[t]{2}{*}{ PPI PT } & $\beta^{\mathcal{E}, X}$ & & & $\begin{array}{c}1.028^{* * *} \\
(0.079)\end{array}$ & $\begin{array}{c}1.023^{* * *} \\
(0.079)\end{array}$ & $\begin{array}{c}1.021^{* * *} \\
(0.079)\end{array}$ \\
\hline & $\begin{array}{l}\text { Adj. } R^{2} \\
\text { Obs. } \\
\text { Sector FEs? }\end{array}$ & $\begin{array}{c}0.000 \\
66,104 \\
\text { No }\end{array}$ & $\begin{array}{c}0.002 \\
66,104 \\
\text { Yes }\end{array}$ & $\begin{array}{c}0.013 \\
66,104 \\
\text { Yes }\end{array}$ & $\begin{array}{c}0.014 \\
66,104 \\
\text { Yes }\end{array}$ & $\begin{array}{c}0.014 \\
66,104 \\
\text { Yes }\end{array}$ \\
\hline
\end{tabular}

Notes: Robust standard errors in parentheses. ${ }^{* * *},{ }^{* *}$, and ${ }^{*}$ denote statistical significance at the 1,5 , and 10 percent level.

Table 6: Regression Analysis of Retaliatory Export Tariffs, Conditional on Price Change

\section{Conclusion}

A rich literature theoretically characterizes the motivations behind enacting tariff policies and the potential implications they carry. Relatively little is known, however, about how economies in practice respond to tariffs, particularly when these trade policies involve large countries that have the potential to influence prices. Will the response of exporters be symmetric across countries? How quickly will prices adjust? Will prices at the border adjust similarly to prices at the store? To answer these questions, we collect and analyze micro data on prices and characterize the reaction of importers, retailers, and exporters to US trade policy since 2018.

We find that tariffs passed-through almost fully to US import prices, implying that much of 
the tariffs' incidence rests with the United States. In these same data, we find far lower rates of passthrough from exchange rate shocks into import prices. Furthermore, despite this rapid increase in the total cost of importing goods, we find more mixed evidence regarding retail price increases, which suggests that many US retailers reduced the profit margin on their sales of the affected goods. Finally, we show how the response of US exporters to foreign retaliatory tariffs was not symmetric to the response of foreign exporters to US import tariffs. Foreign tariffs targeted undifferentiated goods exported by the United States, and US exporters significantly reduced their ex-tariff export prices on these goods, particularly on shipments to China.

Should we expect these same patterns to hold for the medium or longer term if the recently installed tariffs remain in place? We offer some evidence that importers to some extent frontran the recent changes in trade policy and document clear trade diversion away from China. These non-price margins of adjustment suggest that so far, we may have only seen the short-run response to tariffs. 


\section{References}

Amiti, M., S. Redding, and D. Weinstein (2019): "The Impact of the 2018 Trade War on U.S. Prices and Welfare," Working Paper.

Barbiero, O., E. Farhi, G. Gopinath, and O. Itskhoki (2019): "The Macroeconomics of Border Taxes," NBER Macroeconomics Annual, 33.

Bown, C., And M. Kolb (2019): "Trump's Trade War Timeline: An Up-to-Date Guide," https://piie.com/system/files/documents/trump-trade-war-timeline.pdf.

Cavallo, A., M. Cal, and A. Laski (2019): "The U.S. - China Trade War," Harvard Business School Case, N2-719-034.

Cavallo, A., and R. Rigobon (2016): "The billion prices project: Using online prices for measurement and research," Journal of Economic Perspectives, 30(2), 151-78.

Cole, M. T., and C. Eckel (2018): "Tariffs and markups in retailing," Journal of International Economics, 113, 139-153.

DArcy, P., D. Norman, S. Shan, Et AL. (2012): "Costs and margins in the retail supply chain," RBA Bulletin, June, pp. 13-22.

Fajgelbaum, P., P. Goldberg, P. Kennedy, and A. Khandelwal (2019): "The Return to Protectionism," Working Paper.

Farhi, E., G. Gopinath, and O. Itskhoki (2014): "Fiscal Devaluations," Review of Economic Studies, 81(2), 725-760.

Fitzgerald, D., And S. Haller (2018): "Exporters and Shocks," Journal of International Economics, 113, 154-171.

Flanen, A., A. Hortaçsu, and F. Tintelnot (2019): "The Production, Relocation, and Price Effects of US Trade Policy: The Case of Washing Machines," Working Paper.

Goldman Sachs (2019): "US Daily: The Impact of Tariffs on Inflation and Income (Mericle/Taylor)," Economic Research. 
Gopinath, G., O. Itskhoki, and R. Rigobon (2010): "Currency choice and exchange rate pass-through," American Economic Review, 100(1), 304-36.

Gopinath, G., and R. Rigobon (2008): "Sticky Borders," Quarterly Journal of Economics, $123(2), 531-575$.

Gopoinath, G., E. Boz, C. Casas, F. J. Díez, P.-O. Gourinchas, and M. PlagborgMøLler (2019): "Dominant currency paradigm," Discussion paper, National Bureau of Economic Research.

Irwin, D. A. (2014): "Tariff Incidence: Evidence from US Sugar Duties, 1890-1930," Discussion paper, National Bureau of Economic Research.

Nakamura, E., And J. Steinsson (2008): "Five facts about prices: A reevaluation of menu cost models," The Quarterly Journal of Economics, 123(4), 1415-1464.

Neiman, B. (2010): "Stickiness, Synchronization, and Passthrough in Intrafirm Trade Prices," Journal of Monetary Economics, 57(3), 295-308.

RAUCH, J. E. (1999): "Networks versus markets in international trade," Journal of international Economics, 48(1), 7-35. 